\title{
How to implement biodiversity-based agriculture to enhance ecosystem services: a review
}

\author{
Michel Duru $^{1,3}$ - Olivier Therond ${ }^{1,3} \cdot$ Guillaume Martin $^{1,3} \cdot$ Roger Martin-Clouaire $^{2,3}$. \\ Marie-Angélina Magne ${ }^{1,4}$ - Eric Justes ${ }^{1,3}$ - Etienne-Pascal Journet ${ }^{1,3,5}$. \\ Jean-Noël Aubertot $^{1,3} \cdot$ Serge Savary ${ }^{1,3}$ - Jacques-Eric Bergez ${ }^{1,3}$ - Jean Pierre Sarthou ${ }^{1,3}$
}

Accepted: 27 March 2015 / Published online: 10 June 2015

(C) INRA and Springer-Verlag France 2015. This article is published with open access at Springerlink.com

\begin{abstract}
Intensive agriculture has led to several drawbacks such as biodiversity loss, climate change, erosion, and pollution of air and water. A potential solution is to implement management practices that increase the level of provision of ecosystem services such as soil fertility and biological regulation. There is a lot of literature on the principles of agroecology. However, there is a gap of knowledge between agroecological principles and practical applications. Therefore, we review here agroecological and management sciences to identify two facts that explain the lack of practical applications: (1) the occurrence of high uncertainties about relations between agricultural practices, ecological processes, and ecosystem services, and (2) the site-specific character of agroecological practices required to deliver expected ecosystem services. We also show that an adaptive-management approach, focusing on planning and monitoring, can serve as a framework for developing and implementing learning tools tailored for biodiversity-based agriculture. Among the current learning tools developed by researchers, we identify two main types of emergent support tools likely to help design diversified farming systems and landscapes: (1) knowledge bases
\end{abstract}

Michel Duru and Olivier Therond are two first co-authors.

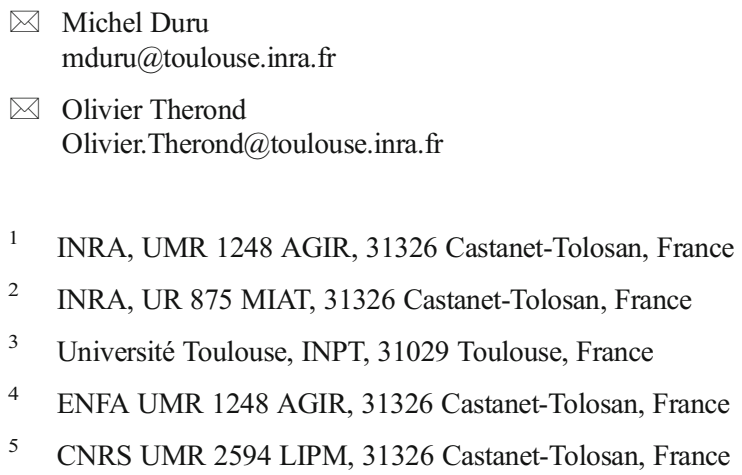

containing scientific supports and experiential knowledge and (2) model-based games. These tools have to be coupled with well-tailored field or management indicators that allow monitoring effects of practices on biodiversity and ecosystem services. Finally, we propose a research agenda that requires bringing together contributions from agricultural, ecological, management, and knowledge management sciences, and asserts that researchers have to take the position of "integration and implementation sciences."

Keywords Adaptive management - Agroecosystem · Functional ecology · Innovation · Landscape ecology · Learning tool $\cdot$ Model $\cdot$ Species traits

Contents

1. Introduction

2. Concepts, principles, and scientific approaches for biodiversity-based agriculture

2.1. Ecosystem structure, processes, and services

2.2. Principles and examples for enhancing ecosystem services

2.3. Main advances in ecology to characterize biodiversity-based ecosystem services

3. Managing transition toward diversified farming systems and landscapes

3.1. Uncertainty and place-based transition

3.2. Learning systems for managing the transition: the key role of adaptive management

4. Building learning support tools to link principles and actions

4.1. Necessary tool features for implementation of biodiversity-based agriculture

4.2. Analysis of weaknesses of some learning-support tools and promises for defining research avenues 
4.2.1. Limits of existing tools for supporting biodiversity-based agriculture

4.2.2. Promising tools for designing diversified farming systems and landscapes

4.2.3. Promising tools for monitoring dynamics of diversified farming systems and landscapes

5. Conclusion and research agenda

6. Acknowledgements

7. References

\section{Introduction}

Farmers manage about $50 \%$ of the Earth's surface, excluding boreal lands, desert, rock, and ice (Tilman et al. 2001). From 1960 to 2000, global food production increased 2.5 times (MEA 2005) due to a large increase in application of fertilizers, pesticides, and irrigation (Foley et al. 2005; Tilman et al. 2002). Application of nitrogen fertilizers is now the main source of reactive nitrogen in the environment (Galloway et al. 2003; Lassaletta et al. 2014). This agricultural intensification has led to a strong homogenization of agricultural landscapes and loss of natural and seminatural habitats (Foley et al. 2005), the biodiversity depending on them (Tilman et al. 2001) as well as soil biodiversity (Tsiafouli et al. 2015). It also has resulted in decreased ecological regulation of water quantity, air and water quality, climate, erosion, and pests and diseases (Foley et al. 2005; Kremen and Miles 2012; MEA 2005; Zhang et al. 2007). More specifically, at the European level, trends over the past 10 years have been as follows (EEA 2010): on-track for reduction in greenhouse gas emissions, water pollution, and waste management; mixed progress for improved energy efficiency, renewable energy production, and water use and quality; but worsening for air pollution, eutrophication, species and habitat loss, and soil erosion. Despite numerous (bio)technological innovations such as precision agriculture and improved genotypes, environmental problems from agriculture still persist, and resources continue to become ever scarcer. For example, it is even anticipated that goals for biodiversity and soil health in Europe will not be achieved (EEA 2010). Faced with these now welldocumented negative impacts of agriculture as well as global changes requires developing more sustainable agricultural systems, i.e., less dependent on anthropogenic inputs and petroleum, efficient resource use, low environmental impacts, resilient to climate change, and producing sufficiently abundant and healthy food (Bommarco et al. 2013; Koohafkan et al. 2011). However, the changes needed to implement this productive and eco-friendly agriculture still remain to be specified. To clarify this, Horlings and Marsden (2011) distinguish between weak and strong ecological modernization and their different paradigms and associated sciences. The former is based on normative ecological and genetic engineering, while the latter relies on agroecological principles that have to be adapted to problems and places. These two forms of ecological modernization necessarily represent two extremes over a range, and strong ecological modernization of agriculture can include principles and mechanisms of weak ecological modernization of agriculture, at least temporarily during a transition phase (Brussaard et al. 2010; Duru and Therond 2014). The efficiency-substitution-redesign (E-S-R) framework developed by agricultural scientists (Hill and MacRae 1995; Hill 1998) also help to inform these two forms of ecological modernization.

Weak ecological modernization of agriculture aims to increase efficiency $(E)$ of input use to decrease production costs and environmental impacts (Horlings and Marsden 2011). This form of agriculture is implemented via best management practices (Ingram 2008), use of precision-agriculture technologies (Buman 2013) or improved plant cultivars (Vanloqueren and Baret 2009), or substitution (S) of chemical inputs by biological and environmentally less harmful ones (Singh et al. 2011). Hereafter, we call it efficiency/substitutionbased agriculture. It corresponds mainly to a "technocentric approach" (Hill 1998): Innovations are most often "technology developments that are economically driven, promoting technological environmental solutions and closed loops of energy, organic matter and minerals" (Horlings and Marsden 2011). Innovators are mainly scientists and agricultural advisors, designing and promoting best agricultural practices, and companies developing and providing technological innovations like plant cultivars and agro-chemical inputs. Research outcomes tend to be "one size-fits-all" recommendations and technologies, and the transfer mode is mainly a top-down process toward farmers. According to this paradigm, farmers' strategies and practices evolve along with research outputs and technologies developed by companies (Klerkx et al. 2012).

Strong ecological modernization of agriculture, hereafter called biodiversity-based agriculture, is similar to "ecologically intensive agriculture" or "eco-functional intensification" (Levidow et al. 2012) or "sustainable intensification of agriculture" (Garnett and Godfray 2012; Pretty et al. 2011). It refers to an ecocentric approach (Hill 1998) that relies on high biological diversification of farming systems (Kremen et al. 2012) and intensification of ecological interactions between biophysical system components that promote fertility, productivity, and resilience to external perturbations (Bellon and Hemptinne 2012; Malézieux 2011). It relies on the development and management of on-farm agrobiodiversity (Fig. 1) to generate ecosystem services and in turn drastically reduce the use of exogenous anthropogenic inputs. It requires site-, space-, and time-specific agricultural practices and production systems (Godfray et al. 2010; Koohafkan et al. 2011; Power 2010). It requires considering and integrating interconnected 


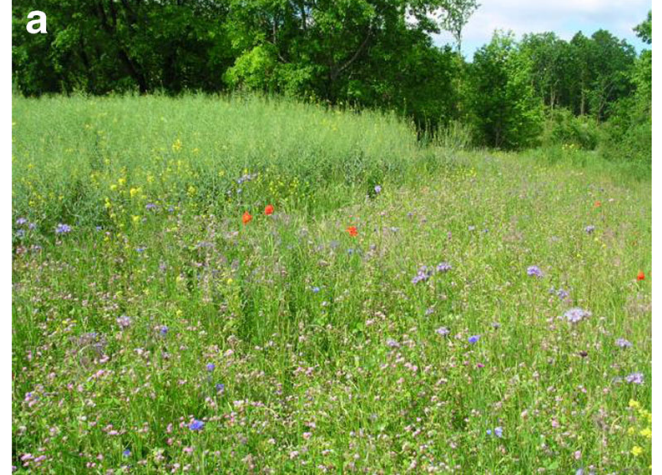

b

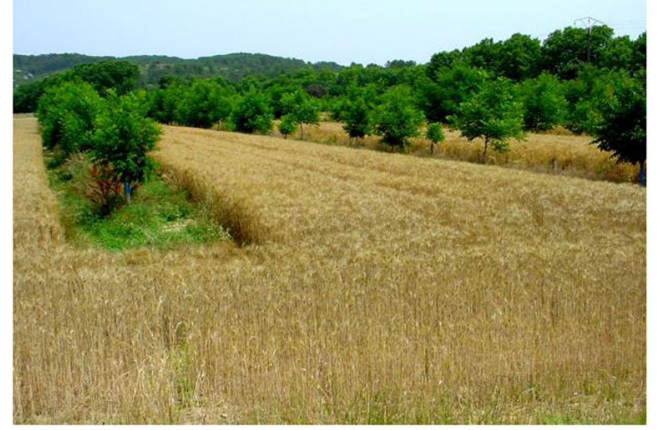

Fig. 1 Examples of two agricultural systems involved in biodiversitybased agriculture: a Flower strip on a crop field margin (here, oilseed rape) implemented to provide habitats for natural enemies of pests and pollinators. b Agroforestry with hardwood tree rows (here, walnut trees) and their grass strips in annual crops (wheat). Both systems aim to increase planned and associated biodiversities, and in turn, ecosystem services (e.g. biological regulations in $\mathbf{a}$ and soil fertility in $\mathbf{b}$ )

processes and organization levels in ecological systems, from, e.g., populations and communities to the landscape (Rabbinge and de Wit 1989), as well as in entire human-technologyenvironment (or social-ecological) systems (Pahl-Wostl et al. 2010). Thus, the development of biodiversity-based agriculture most often requires redesigning $(R)$ farming systems (Hill 1998). It is thus a knowledge-intensive approach that potentially empowers farmers in the quest for agricultural innovations (Horlings and Marsden 2011; Klerkx et al. 2012).

Both forms of ecological modernization of agriculture have specific weaknesses and strengths (Duru and Therond 2014). Despite reducing anthropogenic inputs, efficiency/ substitution-based agriculture can fail to meet some environmental objectives by not fully including negative externalities in agrifood prices (Levidow et al. 2012; Marsden 2012; de Schutter and Vanloqueren 2011). It is a modernization process that does not fundamentally question specialized farming systems and the homogeneous associated landscapes with low crop and animal biodiversity and standardized agricultural practices (Horlings and Marsden 2011). It is strongly supported by public and private applied research and policy (Levidow et al. 2012; Vanloqueren and Baret 2009). The main limitations of efficiency/substitution-based agriculture could be addressed with biodiversity-based agriculture, which, however, has its own weaknesses. Since it has not been as extensively studied, it is not as fully supported by the wider scientific community and well-trained advisory services, therefore, it is hard to implement in practice (Kremen and Miles 2012; Lin 2011; Vanloqueren and Baret 2009). Still, the scientific foundations required to develop biodiversity-based agriculture exist. For example, fundamental research on ecological processes in natural and agricultural ecosystems has been building knowledge about key interactions between biotic and abiotic components. In parallel, many authors have developed theories and general principles to support the development of biodiversity-based farming systems and landscapes (Godfray et al. 2010; Koohafkan et al. 2011; Power 2010). However, management practices and ecological principles falling within either efficiency/substitution- or biodiversity-based agriculture are usually not distinguished in the literature, even though they strongly differ in their underpinning ecological principles and necessary knowledge and way to manage it. Furthermore, applied research integrating the above-mentioned knowledge and principles into methods and tools that can support farmers' decision-making processes during the transition from conventional specialized to biodiversity-based agriculture remains to be developed (Brussaard et al. 2010; Sutherland et al. 2012).

The objective of this paper is to review and analyze challenges of implementing biodiversity-based agriculture. Three questions led our analysis: (i) How is the body of knowledge of this form of agriculture developed and implemented? (ii) What are the difficulties for practitioners in implementing it and the main issues for managing transition towards biodiversity-based agriculture? (iii) Which kinds of relevant tools and methods can researchers build to support development of biodiversity-based agriculture? Our reflection applies to practitioners who have already decided to begin the transition. Consequently, we do not deal with necessary changes in farmers' representations, beliefs, and values that involve the so-called second and third learning loops and the associated methods for their development (see Argyris and Schön 1992; Pahl-Wostl et al. 2010). To address the three key questions, we first examine the main concepts, principles, and scientific approaches for biodiversity-based agriculture from both the agricultural and ecological literature (Section 2). Then, we identify management issues (uncertainty, site-specific management) about transposing generic agroecological principles into practices in specific sites and contexts and argue that organization of knowledge sharing between stakeholders involved in the transition process is essential (Section 3). Based on these two sections, we then focus on learning-support tools needed to support farmer implementation of biodiversity-based agriculture (Section 4). We analyze properties of the tools required to ensure the effectiveness of scientific information and highlight the limits of existing tools mainly developed for 
managing abiotic resources. Therefore, we describe promising existing tools to support development of diversified and sitespecific farming systems and landscapes relying on both local and scientific knowledge. Finally, we propose a research agenda that requires bringing together contributions from agricultural, ecological, management, and knowledge management sciences, and asserts that researchers have to take the position of "integration and implementation sciences" (Brammer 2005).

\section{Concepts, principles, and scientific approaches for biodiversity-based agriculture}

\subsection{Ecosystem structure, processes, and services}

One of the most quoted definitions of ecosystem services is that of Costanza et al. (1997): "the benefits human populations derive, directly or indirectly, from ecosystem functions." More than 10 years later, Fisher et al. (2009), seeking to provide a consistent and operational definition, proposed that "ecosystem services are the aspects of ecosystems utilized (actively or passively) to produce human well-being." Here, ecosystem aspects correspond to both the structure and processes (or functions) of ecosystems. Ecosystem structure encompasses composition (nature and abundance) and organization (spatial distribution) of biotic and abiotic components (entities). Ecosystem services often derive from complex interactions between ecosystem structures and intricate networks of ecological, biochemical, and physical processes (Fisher et al. 2009; De Groot et al. 2010) occurring at the field, field margin, and landscape levels (Power 2010).

Since the Millennium Ecosystem Assessment (MEA 2005), ecosystem services are usually classified into four categories: provisioning services (i.e., products obtained from ecosystems such as food, forage, feed, fiber, and fuel), regulating services (e.g., climate regulation), cultural services (i.e., non-material benefits such as aesthetic and recreational enjoyment), and supporting services, i.e. feedback services, that are necessary for proper delivery of the other three types of services, such as nutrient cycling. Focusing on relations between ecosystem services and agriculture, Zhang et al. (2007) and Swinton et al. (2007) highlighted that agriculture both provides and receives ecosystem services. Zhang et al. (2007) identified supporting and regulating services as services to farming systems (agroecosystem) and provisioning and non-marketed services as services from agricultural systems. In the same logic, still focusing on agriculture, Le Roux et al. (2008) categorized services into "input services" (to farming systems) and "output services" (from). Input services include MEA's "supporting services" (e.g., soil fertility, microclimate regulation) and "regulating services" (e.g., pollination, natural pest control) (Figs. 2, 3, and 4). "Input services" enable farming systems to depend less on marketed inputs, e.g., mineral fertilizers, pesticides, and irrigation water. "Output services" include what we call hereafter "agricultural services" that are marketed with their quantitative and qualitative properties (e.g., cash crops, milk, meat), and "environmental services" that are nonmarketed, e.g., cultural value. Input services are also intermediate services for society (Fisher et al. 2009) since they determine agricultural and nonmarketed services while reducing the use of anthropogenic inputs.

The geographic area of ecosystem service production may be different from the area of ecosystem service benefit (Fisher et al. 2009; Serna-Chavez et al. 2014). While for soil fertility, service production and benefit occur on the same area, i.e., the field, through the harvested crop, for biological regulations, the areas can be spatially disconnected if the species involved fulfill phases of their biological cycles in different habitats. This can lead to mismatches between actual management levels of an agroecosystem and higher levels at which ecosystem services should be managed (Pelosi et al. 2010). Hence, while certain ecosystem services can be managed only at field and field edge, e.g., interstitial spaces, levels, e.g., management of endocyclic pests (Aubertot and Robin 2013), other services are derived from more mobile organisms that depend on management of landscape heterogeneity (Power 2010).

Efficiency/substitution-based agriculture aims to increase input-use efficiency by optimizing and synchronizing supplies of biological needs through precision agriculture, substitution of chemical inputs with organic and ecological ones, and improvement of recycling. This contrasts with conventional agriculture, in which limiting and reducing production factors are compensated by high use of anthropegenic inputs. Conversely, biodiversity-based agriculture aims to develop input services as a way to substitute inputs by redesigning farming systems without significantly decreasing agricultural production (Figs. 2 and 3), as previously shown in a meta-analysis comparing conventional and organic agriculture (Ponisio et al. 2014).

In agricultural systems, ecosystem services are determined by land use management (Fig. 4c) along with soil and climate conditions. Land use determines spatiotemporal distribution of biotic (biodiversity) components of managed ecosystems (landscape structure) and the state of abiotic components, e.g., soil nutrient and water levels. Both components may boost biological processes (biological regulation and resource capture) and in turn the nature and strength of the services. Biodiversity has recently been recognized as playing a major role in this sequence of events. Three main components of biodiversity can be distinguished in agroecosystems (Altieri 1999; Fig. 4b). Planned biodiversity refers to the diversity of cash crops, forage or cover crops (species and varieties), and livestock (species, breeds and genotypes) that are intentionally chosen by the farmer, and their spatial/temporal layouts (Fig. 4a). It thus has, before all others, a productive function. 


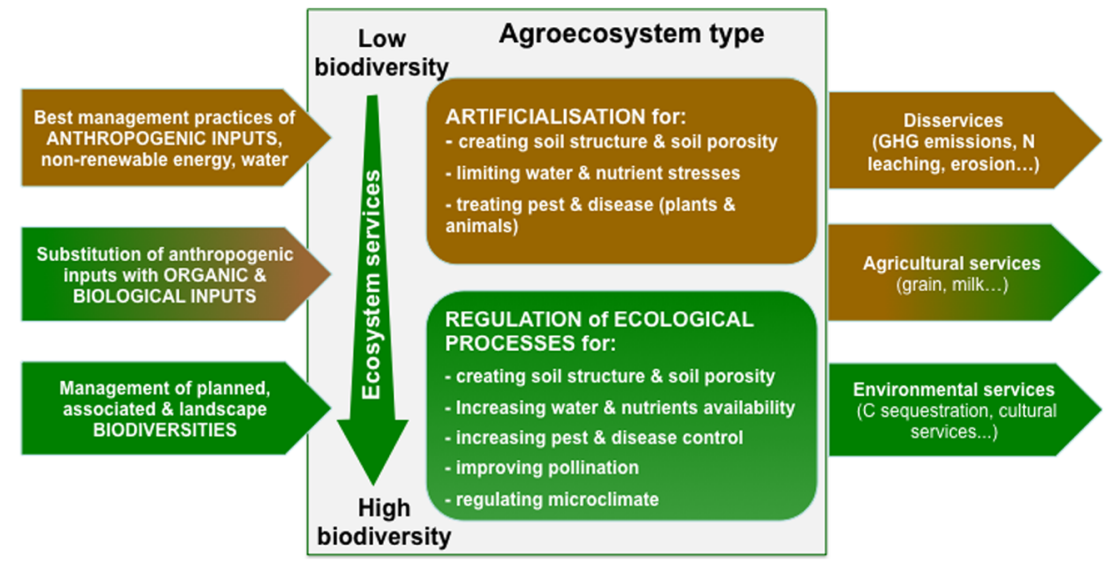

Fig. 2 Synoptic representation of the main characteristics of the efficiency/substitution-based agriculture (brown) and the biodiversitybased agriculture (green), i.e., agricultural production mode based on efficient (optimized) use of anthropogenic inputs to one harnessing biodiversity to promote input (ecosystem) services (biodiversity-based agriculture). These two opposing strategies develop two different types of agroecosystem. The color code (brown to green) indicates the relative

The second component, associated biodiversity, includes not only all organisms that inhabit cultivated areas or colonize them from surrounding habitats, such as insect pests but also intensities of inputs (anthropogenic vs. input services) and of the main types of outputs in both strategies. Input services are those provided to farming systems. They correspond to "supporting services" (e.g., soil fertility, microclimate regulation) and "regulating services" (e.g., pollination, natural pest control). Agricultural services (provisioning services) and environmental services (nonmarketed services) are those provided by agriculture to the whole society

their natural enemies and pollinators, which provide input services and possibly disservices (Fig. 4c). Last, associated diversity depends on landscape diversity, i.e., the

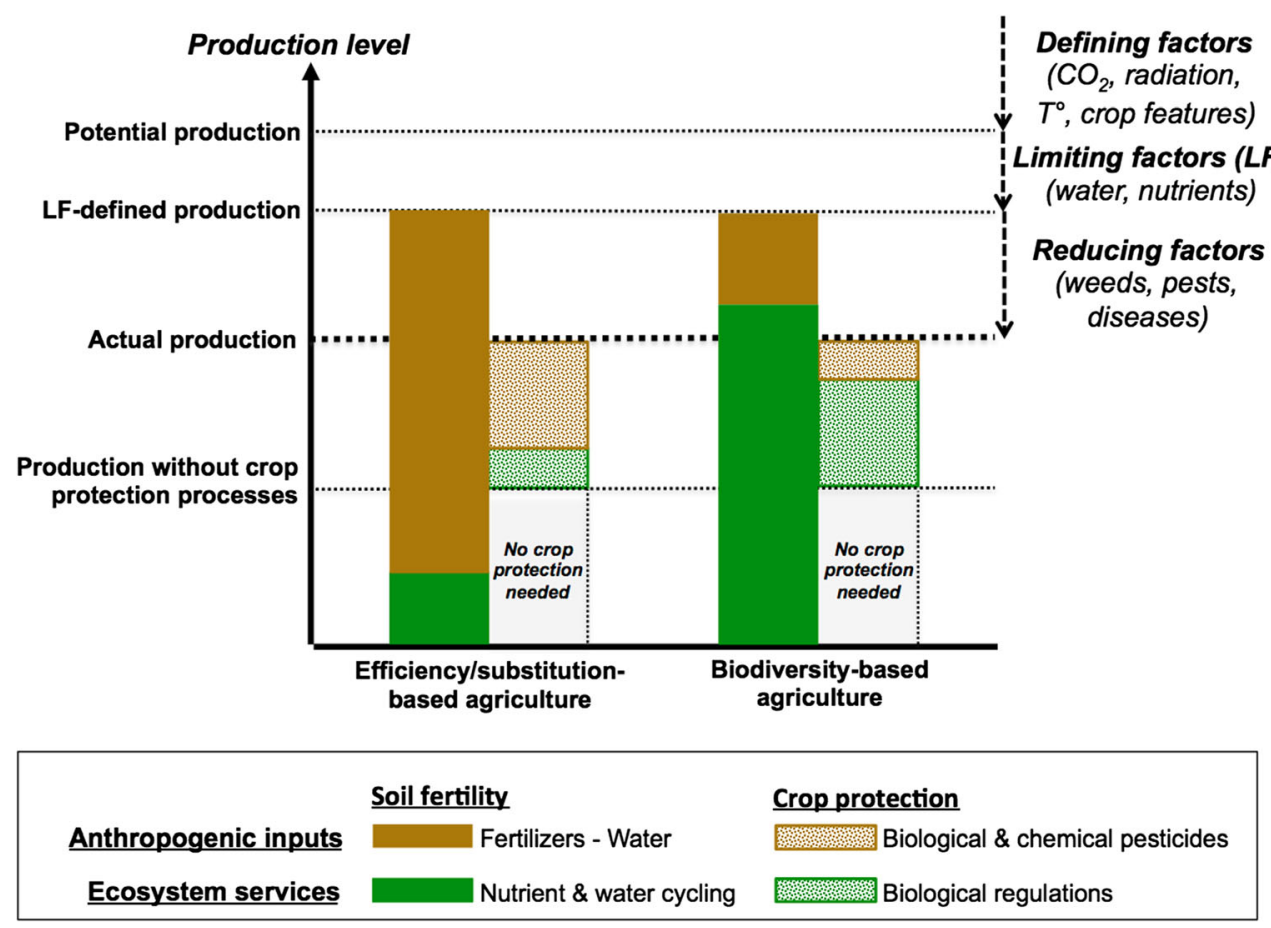

Fig. 3 Conceptualization of the contribution of anthropogenic inputs vs. input ecosystem services for two different forms of agriculture providing the same level of production. Given the potential production determined by "defining factors," actual production is determined by (abiotic) "limiting factors" and (biotic) "reducing factors" (Ittersum and Rabbinge 1997). Limiting factors-defined production is that which can be reached when all reducing factors are compensated. Production without crop protection processes is that reached when no control of weeds, pests, and diseases is performed, either through anthropogenic actions (e.g., pesticide applications) or natural biological regulation. For simplification purposes, the level of production without crop protection processes is assumed to be the same for the two different forms of agriculture. In efficiency/substitution-based agriculture, limiting and reducing factors are compensated mainly by anthropogenic (e.g., fertilizers and pesticides) or biological inputs (e.g., industrially produced and marketed enemies of pests), while in biodiversity-based agriculture, they are compensated by ecosystem services (soil fertility and biological regulation, respectively) provided by the agroecosystem, especially by associated biodiversity (e.g., natural enemies of pests) 


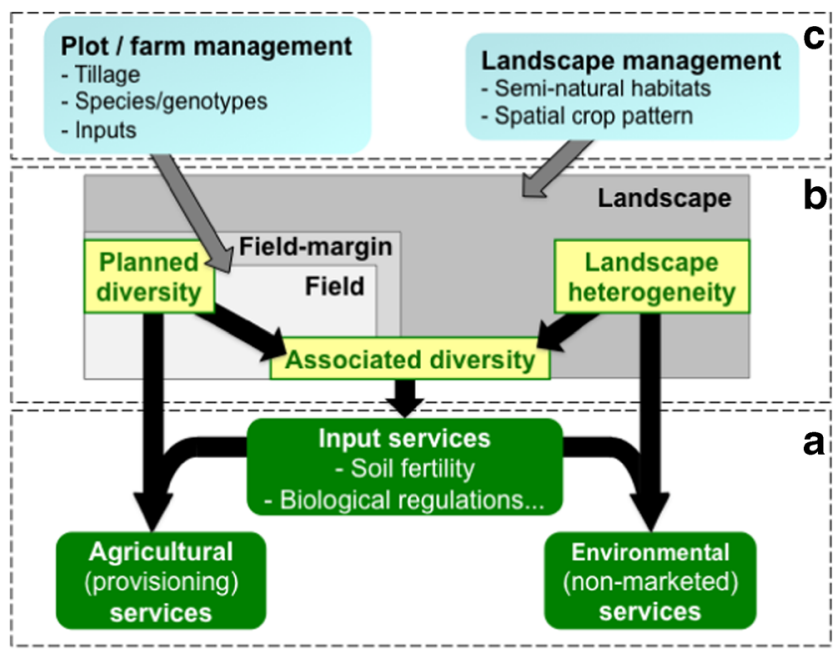

Fig. 4 Integrated diagram of relations between the ecosystem services provided by agroecosystems (a adapted from Le Roux et al. 2008), among the three types of biodiversity and ecosystem services $(\mathbf{a}+\mathbf{b}$ adapted from Altieri 1999), and between management levels and actions and diversity (b+c adapted from Power 2010)

spatiotemporal composition and configuration of crop, grassland, and seminatural interstitial areas (Fahrig et al. 2011). These three components of biodiversity are obviously mediated through management practices.

The above conceptual approaches have been validated by empirical research. For example, a recent meta-analysis (Quijas et al. 2010) investigated the effect of plant diversity (planned and associated) on several ecosystem services and showed a clear positive effect on six out of eight services analyzed: provisioning of plant products, erosion control, soil fertility regulation, invasion resistance, pest regulation, and plant pathogen regulation. More specifically, literature suggests that increasing plant biodiversity in cultivated ecosystems can reduce the impact of weeds, animal pests, and diseases by the following mechanisms: (i) resource dilution and stimulo-deterrent diversion, (ii) disruption of spatial cycles, (iii) disruption of the temporal cycle, (iv) allelopathy effects, (v) general and specific soil suppressiveness, (vi) crop physiological resistance, (vii) conservation of natural enemies and facilitation of their action against aerial pests, and (viii) direct and indirect architectural/physical effects (Ratnadass et al. 2012). We posit, based on the literature, e.g., Eisenhauer et al. (2012)), that for mechanism (vii), the action of natural enemies can be broadened to soil pests. It is now well recognized that heterogeneous landscapes, having high spatiotemporal biodiversities from field to the entire landscape level (Fig. 5), allow the recovery of high associated biodiversity and a high level of biological control in crop fields (Veres et al. 2013). This provides resilience and stability of ecological processes in changing environments and corresponds to the landscape-moderated insurance hypothesis of Tscharntke et al. (2012). Thus, biodiversity appears to regulate ecosystem processes and determine delivery of ecosystem services, even though some authors claim that its role in producing ecosystem services remains to be fully understood (De Groot et al. 2010). One certainty stands out: To deliver expected ecosystem services, the right combination of certain biotic and/or abiotic components has to occur at the right place and at the right time (Mace et al. 2012).

\subsection{Principles and examples for enhancing ecosystem services}

Biggs et al. (2012), through their thorough review of the scientific literature and expert knowledge, identified three key properties of the ecosystem to be managed that determine the intensity and resilience of ecosystem services: (i) the functional diversity-redundancy level, (ii) the ecological connectivity level, and (iii) the state of slow dynamic variables. Functional diversity and redundancy determine the degree to which substituting one set of ecosystem components with another can meet a biological function and hence one or several ecosystem services. While high diversity-redundancy is required to reinforce ecosystem services, above a given threshold, it can lead to a system whose functioning is cumbersome, complex, less efficient, less resilient, and with low adaptive capacity. Connectivity describes spatial relations between ecosystem components and landscape elements, e.g., patches). It determines biotic interactions and species dispersion capacities between species habitats (Tscharntke et al. 2005). Connectivity can promote migration of individuals from distant source habitats to locally restock after perturbation. High connectivity may also promote massive propagation of local perturbations (e.g., invasive alien species and pest and disease propagation, Biggs et al. 2012). However, potential negative impacts of high connectivity are still a subject of discussion. For example, Haddad et al. (2014) found no evidence that corridors increase unwanted disturbances or invasions of non-native species. The dynamics of complex ecosystems are determined by the interaction between slow variables, e.g., soil organic matter and water-holding capacity, and fast variables, e.g., soil mineral nitrogen and water flow. The former determine the conditions under which the latter occur. The middle- or long-term management of slow variables thus affects day-to-day system functioning.

Several authors (e.g., Altieri 1999; Kassam et al. 2011; Kremen et al. 2012), focusing on sustainable agriculture, agree about principles for designing agricultural practices that favor an increase in input services. They can be summarized into three prime-order agroecological principles at field (the first two) and landscape (the last one) levels:

- Increasing plant diversity and soil cover through adapted crop sequences, including intercropping and mixtures during and over years, to decrease nutrient and radiation losses (e.g., cover crop to decrease nitrate leaching or 
Fig. 5 Key mechanisms of agroecological practices: the increase in plant diversity in time $(X$-axis) and in space ( $Y$-axis) at field, field margin, and landscape levels. They allow development of key properties of agroecosystems that ensure delivery and resilience of ecosystem services: functional diversity, connectivity, and control of "slow variables." The third key principles of an agroecological transition toward a biodiversity-based agriculture, a reduction in soil disturbance, is not explicitly represented in this figure

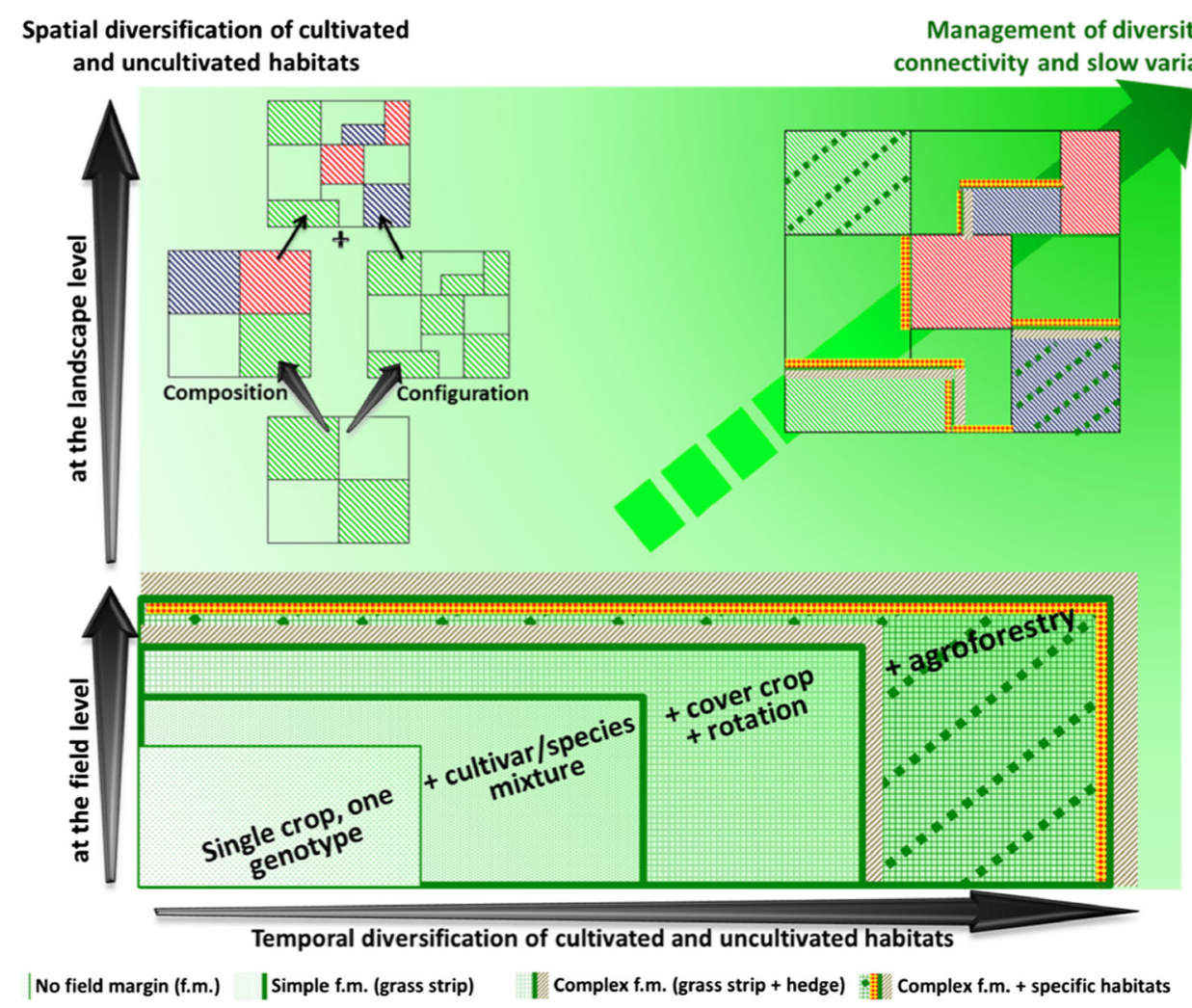

recycle nutrients) and increasing above- and underground biomass production and rhizosphere deposition to, in turn, increase biological, physical and chemical soil fertility, and biological regulations (horizontal axis in Fig. 5)

- Minimizing mechanical and chemical disturbances of soil functioning and, whenever possible, seeding or planting directly into untilled soil to (i) increase soil organic matter of the upper layer $(0-5 \mathrm{~cm})$, which can improve some soil physical properties, e.g., water infiltration, and (ii) support development of soil microflora as well as soil micro-, meso-, and macrofauna promoting soil fertility and biological regulation, and hence improve soil structure

- Organizing the landscape matrix (spatial crop distribution, grass trip, hedgerow, and other seminatural habitats...) to increase biological regulation (vertical axis in Fig. 5)

Applying these agroecological principles indeed aims to ensure functional diversity and redundancy, connectivity, and the management of slow variables (oblique axis in Fig. 5).

At the field level, the objective of rotating crops and mixing plants is to enhance functional complementarity, beneficial biological interactions, and synergisms between plant species and genotypes of the agroecosystem both in time and in space. They consist of spatiotemporal assemblages of annual and/or perennial plants, in association in the landscape and possibly in the field that can include trees, shrubs, pastures, and crops. It aims to provide benefits from "preceding effects" and "cumulative effects". The "previous effects" include changes in physical, chemical, and biological soil states caused by the previous crop having effects on the behavior of the next crop (Sebillotte 1990). "Cumulative effects" include the accumulation over time of the effects of crop rotation and associated parameters. More precisely, these plant successions have effects on:

(i) Soil structural stability (strongly influenced by organic matter content), which has an impact on air, water, nutrient concentrations, distribution, and accessibility by the plants, root growth and morphology (penetration), erosion, or crusting

(ii) Organic matter characteristics (of crop residues and soil) that determine microbial activity and nutrient availability

(iii) Nutrient cycling based on biologically driven processes, which recouple $\mathrm{C}, \mathrm{N}$, and $\mathrm{P}$ cycles through, e.g., nitrogen fixing legumes, $\mathrm{C} / \mathrm{N}$ ratio and mineralization rate of crop residues, and plant-excreted organic acids and/or exogenous enzymes increasing $\mathrm{P}$ bioavailability (Drinkwater 2007)

(iv) Nutrient losses (and sources of pollutants), such as nitrogen loss, nitrate, and sulfate leaching

(v) Weed management via resource competition or allelopathy

(vi) Control of pests and diseases via the seven mechanisms presented in Section 2.1.

Growing plant mixtures in cash crops (intercrops) and cover crops during the period between cash crops can support 
complementary synchronized processes for nutrient capture and recycling, mainly based on complementary root and aboveground biomass morphologies to increase resource capture (e.g., Justes et al. 2012). Intercrops are effective for improving the use of natural abiotic resources such as water and nitrogen, mainly in low-input cropping systems, by enhancing expression of positive interactions (Bedoussac and Justes 2010). They also help reduce weeds and soil-borne diseases and pests (Ehrmann and Ritz 2014). Introduction of legumes into crop mixtures and rotations increases $\mathrm{N}$ resources, strengthens disease resistance, and reduces $\mathrm{N}_{2} \mathrm{O}$ emissions (Bennett et al. 2009). In synergy with these spatiotemporal diversifications, reduced or no soil tillage and continuous soil coverage can increase soil biological activity and lead to high crop production if applied simultaneously, to avoid management difficulties such as lack of weed control (Brouder and Gomez-Macpherson 2014).

At larger spatial scales, landscape configuration and composition, also called the "landscape matrix," strongly determines pest-control processes (Power 2010; Tscharntke et al. 2007). For instance, adapted cropping practices at the landscape level can help limit the development of plant pathogens and the adaptation of pathogen populations to specific cultivar resistances (Lô-Pelzer et al. 2010). Land use management, including seminatural habitat management, determines habitats and resources (food, refuges, hibernation, and estivation shelters) and the availability of pests, their natural enemies, and pollinators, and thus biological control processes (Landis et al. 2000).

Ecological processes at field, farm, and landscape levels may interact strongly. Many pest-management studies have highlighted that adapted management strategies at multiple levels are needed to greatly reduce pesticide use (Médiène et al. 2011; Rusch et al. 2010; Scherr and McNeely 2008). This has been widely reported for integrated pest management (IPM, Médiène et al. 2011; Shea et al. 2002). For ecosystem services, depending on mobile-organism diversity, the effectiveness of local management strategies, for example at the farm level, will vary according to the complexity of surrounding landscape. Biological regulations will be low in cleared, i.e., extremely simplified, landscapes where most biodiversity has already been lost, but sometimes also in complex landscapes, where biodiversity and associated functioning such as pest biocontrol or crop pollination are already high (O'Rourk et al. 2010; Tscharntke et al. 2005). This assertion, expressed by Tschartnke et al. (2012) in their "intermediate landscapecomplexity hypothesis," converges with the hypothesis of Biggs et al. (2012) that argues that diversity-redundancy and connectivity are necessary to ensure provisioning and resilience of ecosystems services. The challenge is thus now to better link studies of both farmland and landscape structure, including crop spatial distribution, to the main features of pest populations, their natural enemies, and pollinators. In such multilevel management and ecological processes, potential cascading effects can occur, leading to virtuous or vicious circles according to the scale of the process or space considered (Galloway et al. 2003). For example, for biological control, it has been shown that low-intensity practices at the field and farm levels, e.g., lower insecticide inputs and levels of disturbance associated with decreasing area of annual crops, are essential to maintain effective biological control by parasitoids at the landscape scale (Jonsson et al. 2012).

\subsection{Main advances in ecology to characterize biodiversity-based ecosystem services}

Management strategies aiming to increase provision of input services raise or exacerbate two knowledge issues that science can help address: (i) how to characterize functional biodiversity for sets of organisms (Brussaard et al. 2010; Moonen and Ba 2008), and (ii) how to model interactions among environmental perturbations (including farmers' management practices), functional biodiversity, and ecosystem services (Cardinale et al. 2012; Gaba et al. 2014). We identify two main research domains that deal with these two issues: functional ecology and landscape ecology.

Identifying causes and mechanisms of changes in community structure of plants, animals, and soil biota is a key challenge in ecology for predicting the dynamics of ecosystems and associated services. The need to transfer knowledge gained from single species to a more generalized ecosystem-based approach has led to the development of categorization methods in which species with similar traits (morphological, phenological, physiological, and ecological characteristics) and associated life strategies are classified into ecological groups such as functional groups/types or guilds. Plant-trait approaches can be used to rank species' strategies for capturing resources and abilities to coexist, e.g., in relation to plant architecture: niche complementarity vs. facilitative interactions. These approaches often group species according to their adaptive strategies when faced with changes in their environments (response traits) and/or their function in the ecosystem (effect traits). While taxonomic classification does not indicate the ability of organisms to provide specific ecosystem services (unless exhaustive and accurate databases are available, which is not the case to date), functional compositions of communities are directly related to effect traits (Lavorel and Garnier 2002) and, in turn, to ecological functions. Functional ecology concepts and methods allow prediction of changes across temporal and spatial modifications in functional groups and in turn ecosystem functioning, considering given changes in the agroecosystem, e.g., changes in land use.

In agriculture, plant-trait approaches are useful, for example, for identifying grain-legume intercrops of cereals that increase forage production effectively (Dordas et al. 2011). 
Traits are also particularly useful for identifying cover crops that best limit weed development (Tixier et al. 2011) and crop successions that allow anthropogenic inputs to be reduced (Smith et al. 2008). Traits can also be used to characterize organisms that are harmful for the crop and their relations with production situations and system performance, e.g., traits associated with foliar disease for wheat (Bingham et al. 2009; Willocquet et al. 2008). Similarly, trait-based approaches should give new highlights for predicting weed-community assemblages and impact on agroecosystem services, especially in complex communities for which a detailed mechanistic and modeling approach based on in-depth knowledge of all organisms involved would not be practical (Navas 2012). For example, soil food-web features can be indirectly assessed through plant functional types considered as proxies (Duru et al. 2013). A trait-based approach was recently applied to multitrophic systems composed of plants and pollinators (Lavorel et al. 2013). However, studies linking environmental perturbations or stresses, ecological groups, and ecosystem services are based on descriptive statistics, and cropping system models that simulate such interactions are still in their infancy.

At the landscape level, efforts have been made to characterize relations between seminatural habitats (e.g., composition and configuration of hedgerows), forests, and the main features of functional biodiversity, e.g., type of predator and pest populations. To characterize hedgerows and networks of hedgerows, Larcher and Baudry (2012) defined a "grammar" (trees and shrubs of different species, hedgerows, and hedgerow networks) that helps to decipher their structural effects (e.g., height, width, connectivity) and functional effects (e.g., reservoir effect for beneficial insects). It also allows rules for their design and management to be formalized. With a similar objective, Herzog et al. (2012) developed a core set of farmland habitat indicators estimated with a standard mapping procedure based on a generic system of habitat definitions, itself based on management intensity and Raunkiaer's plant life forms (Raunkiær 1934). This indicator set has been used to link farmland habitats (seminatural and cultivated) to functional biodiversity, e.g., wild bees as pollinators, spiders as generalist predators, and earthworms as soil engineers, and assess the main drivers of species richness and diversity of these organisms in agroecosystems (e.g., Lüscher et al. 2014; Schneider et al. 2014). In a similar approach, including a more precise description of seminatural habitats at the farm level and a classic coarser description at the landscape level, Sarthou et al. (2014) demonstrated that explanatory variables of seminatural habitats shaping different communities of overwintering natural enemies (i.e., all classic generalist and aphidophagous natural enemies of pests, including spiders, lacewings, Hymenopteran parasitoids, rovebeetles, and predatory species of ground beetles, hoverflies, and ladybugs) have a decreasing influence from the local level (field) to the "mid-distant landscape" (60-120 m) to the "distant landscape" (120-500 m). Such findings indicate powerful mechanisms available to farmers to favor beneficial insects by managing seminatural habitats at the farm level and, in contrast, less influential landscape features that farmers have less control over. Regarding the influence of landscape structure on trophic levels, several studies have demonstrated that predators and parasitoids appear to respond at smaller spatial scales than herbivorous insects (Brewer and Goodell 2012; O'Rourk et al. 2010) and may be more susceptible to habitat fragmentation (Kruess and Tscharntke 2000). Complementarily, Thies et al. (2003) argue for the general idea that higher trophic levels are more sensitive to landscape simplification, indicating a great need to analyze and understand the effect of landscape on biological regulations.

In brief, recent advances in functional ecology and landscape ecology make it possible to better characterize functional diversity for sets of organisms and to better model interactions between environmental factors and ecosystem services.

\section{Managing transition towards diversified farming systems and landscapes}

\subsection{Uncertainty and site-based transition}

When seeking to implement biodiversity-based agriculture, farmers have to lead the transition from the current conventional farming systems to diversified systems and, if necessary, to more diversified landscapes. They have to drastically change aspects of the ecosystem they manage. Current systems are highly artificialized and simplified "agrosystems" in which nutrient availability and pest and disease control are mainly managed for a short-term horizon through tillage and use of exogenous anthropogenic inputs. In a diversified system, the management target is an "agroecosystem" in which soil fertility and biological regulations rely mainly on a complex network of ecological processes. The transition at issue here corresponds to a shift from top to bottom in Fig. 2, from left to right in Fig. 3, and from bottom left to top right in Fig. 5. In diversified systems, farmers seek to avoid soil disturbance to favor beneficial associated biodiversity and use exogenous inputs sparingly to not reduce expected short- and long-term benefits of input ecosystem services (Pisante et al. 2015). During this transition (Fig. 6), it is possible that variability in the magnitude of ecosystem services may significantly increase until slow variables and ecosystem structure reach a configuration in which input and output services are provided at the expected levels and, in turn, provide biophysical resilience and recovered stability (less variable performances). For example, positive effects of conservation agriculture, through implementation of its three principles (no-till, permanent soil cover, and crop rotation), may be provided after several years,

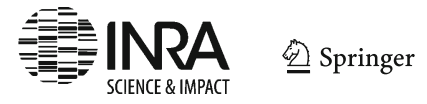


Fig. 6 Representation of the transition as a regime shift from simplified and specialized conventional agricultural systems (involved in efficiency/ substitution-based agriculture or not) to biodiversity-based agricultural systems. The main objective of this transition is to replace anthropogenic inputs by input (ecosystem) services to deliver agricultural services (provisioning services). The variability of input (ecosystem) services is expected to increase during the transition, before recovering to a similar or even lower level, since the new regime is expected to be more resilient than the initial one

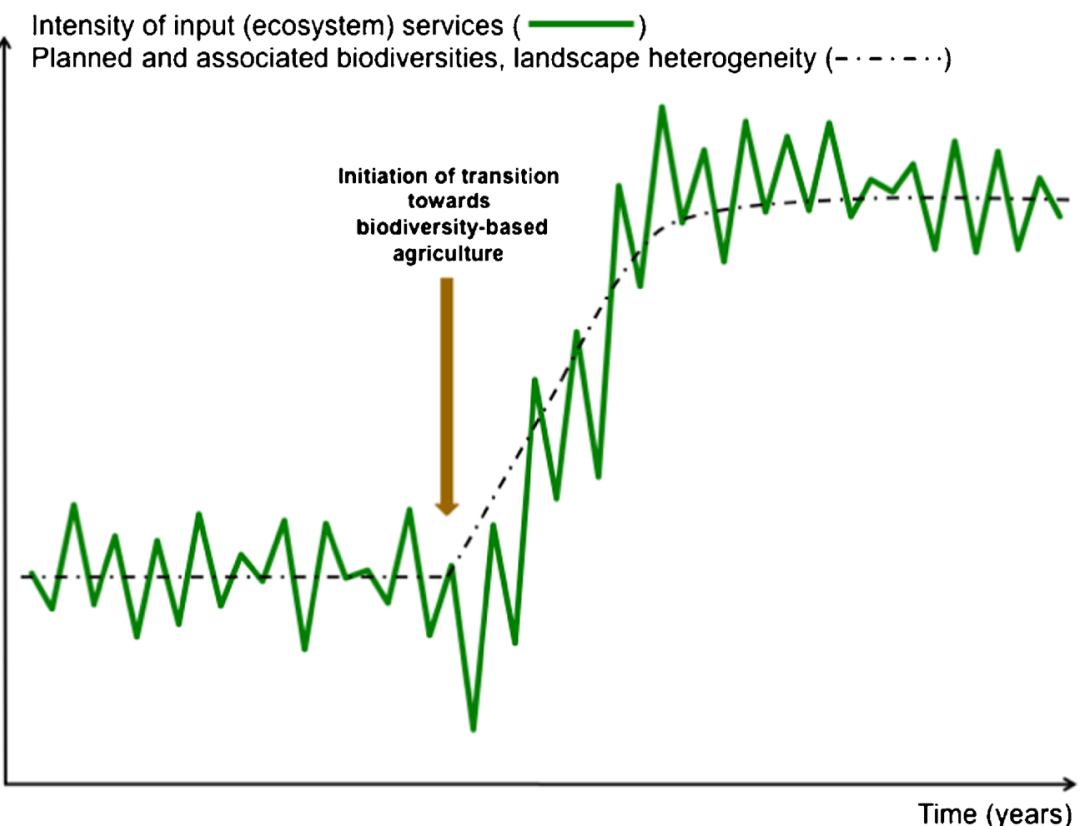

possibly more than ten. Implementation of only one or two of these principles may lead to negative effects, especially on yields (Pittelkow et al. 2014). Furthermore, a single tillage event may significantly damage soil quality, since it can lead to loss of sequestered soil carbon and years of soil restoration (Pisante et al. 2015). During this transition, farm managers must implement new agricultural practices, often ill-known, to develop agroecosystems with a high level of diversity-redundancy and connectivity that correspond to "complex adaptive systems" (Biggs et al. 2012). These systems are characterized by multilevel heterogeneity, cross-level interactions, distributed control, and a high capacity of self-organization and adaptation, including to biological imbalance caused by pests. These "hierarchical nested complex systems" are composed of multiple interacting subcomponents, highly connected, whose behaviors give rise to emergent structures and nonlinear processes that are space and time dependent (e.g., Anand et al. 2010; Parrott 2010; Parott and Meyer 2012; Wu and David 2002). In these systems, specific patterns are detectable only at particular functional levels or spatial and temporal scales (Giampietro 2002). Because of this set of characteristics, predicting their evolution has high uncertainty (Anand et al. 2010; Parrott 2010). More precisely, the uncertainty lies in the intrinsic, chaotic character of and lack of knowledge about some ecological processes and the fact that expected ecosystem services over seasons and years are produced from a complex network of ecosystem processes, which are often incompletely understood (Anand et al. 2010; Fisher et al. 2009; Williams 2011). It is also linked to the interaction between climate variability and agroecosystem functioning. Furthermore, ambiguous biophysical phenomena can be observed. For example, landscape complexity with various and well-represented seminatural habitats may harbor more diversified natural-enemy communities but may also provide better and more abundant overwintering sites for pests (Rusch et al. 2010). Uncertainty also comes from difficulty in measuring multiple effects of multiple practices on biodiversity, particularly associated biodiversity, and even on abiotic system entities (Greiner et al. 2009). This is particularly the case for reduced or no tillage in conservation agriculture (Swenson et al. 2009). Finally, uncertainty also relates to the difficulty, even impossibility, in accessing complete and accurate information about land-use practices at the landscape level, especially in time for management decisions (Williams 2011). This is particularly true when "pest managers" seek to adapt landscape heterogeneity to disrupt pest cycles and increase abundance of beneficial arthropods (Wortman et al. 2012), which moreover may lead to conflicting recommendations.

These sources of uncertainty can make it difficult to design and grow adapted crop mixtures, intercrops (mixtures of species for grain or forage), or crop rotations to provide expected services (Amossé et al. 2013). Moreover, managing slow variables greatly increases the timespan that must be considered in management decisions. Hence, it is difficult for farmers to observe and assess long-term effects of practices, e.g., cumulative effects and installation of a community of beneficial insects (MacLeod et al. 2004), before an observable threshold is crossed. These types of uncertainties make it difficult to collect relevant information about relations between practices and biodiversities (planned, associated, at different spatial scales) on the one hand and between biodiversity and ecosystem services on the other hand (Table 1). They force farmers to 


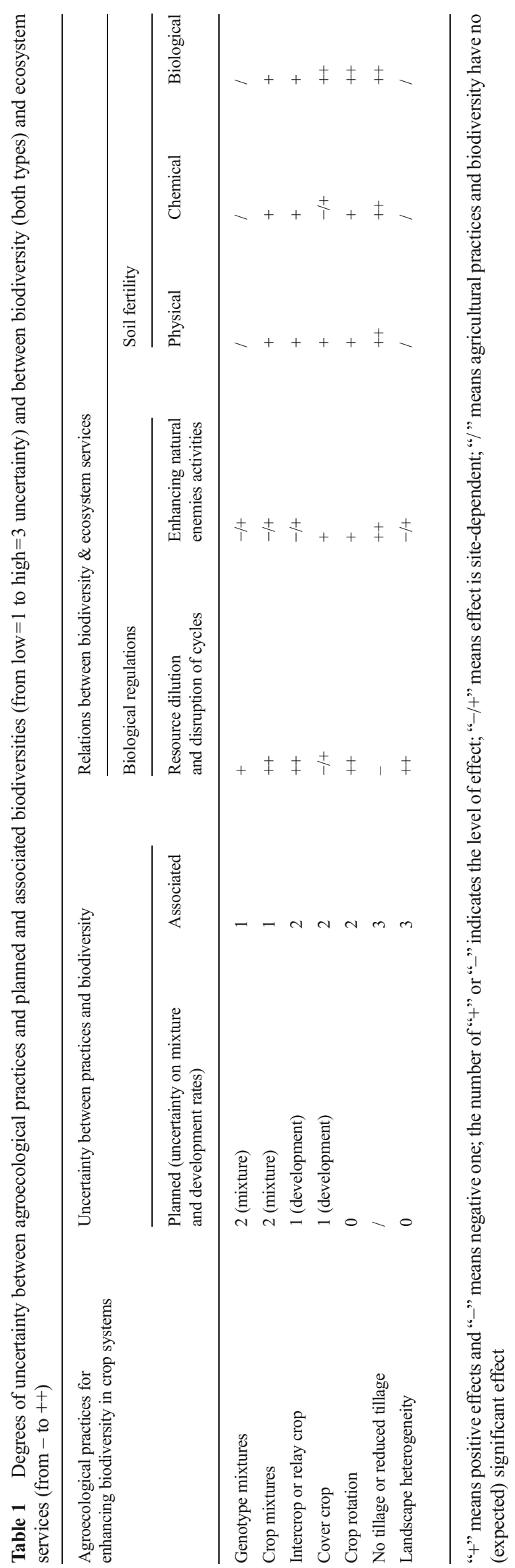


deal with relatively complex and incomplete knowledge and thus to implement management while acknowledging these uncertainties.

In addition to uncertainties about biophysical entities and processes, there are social-based uncertainties due to different or contradictory representations of ecosystem services among stakeholders, their respective importance and priority, and the adapted-management mechanisms to use to promote such services (Barnaud et al. 2012). The more numerous and diverse are the farming systems and landscape-matrix management of stakeholders, the greater the difficulties in developing shared objectives and thus achieving consistency among stakeholder practices. Regardless of the domain considered, biophysical or social, management complexity and issues increase with the number of organization levels considered. This increase in management complexity and issues is intrinsically bound to the complex hierarchical nested system considered: the more hierarchically nested levels and domains, the more interactions between components within and between levels and domains (Ewert et al. 2011).

Finally, more than anything, agroecological practices have to be adapted to the unique characteristics of each production site, regardless of the ecosystem processes and services considered (Caporalli 2011). In this way, plant-soil interactions (Eviner 2008), especially in conservation agriculture (Koohafkan et al. 2011), plant nutrition and soil fertility (Doltra and Olesen 2013; Drinkwater 2009), pest management (Rusch et al. 2010; Médiène et al. 2011), and biological regulations (e.g., Malézieux 2011; Shennan 2008) greatly depend on the site, i.e., the field and its environment.

When implementing biodiversity-based agriculture, while agroecological mechanisms are numerous, the challenge for farmers lies in designing, implementing, and managing consistent cropping and farming systems, and possibly, in interaction with others stakeholders, landscape structures that promote a high level of input services, and consequently of agricultural services in their production situations. In other words, farmers have to identify, in a large space of possible options, the adapted spatiotemporal distribution of planned biodiversities and agroecological practices that allow them to reach their objectives while respecting their constraints. During this transition, while faced with numerous uncertainties and ambiguities, farmers have to identify and implement ill-known complex practices, the effectiveness of which depends greatly on their production situations.

\subsection{Learning systems for managing the transition: the key role of adaptive management}

Since biodiversity-based agriculture is more context dependent than efficiency/substitution-based agriculture, innovation systems are more knowledge intensive and must combine locally relevant empirical knowledge with scientific process- based knowledge (Klerkx et al. 2012). Coping with the resulting higher level of uncertainty of biodiversity-based agriculture (Table 1) requires more training and learning for farmers (Röling and Wagemakers 1998).

To face the uncertainties described above, and ill-known and site-based practices, farmers use a variety of networking devices to support learning, especially sharing experiences with other farmers (Ingram 2010), for instance in farmer field schools. Demonstration, training programs, and brainstorming sessions are also important for designing and implementing agroecological management practices that are necessarily knowledge intensive (Coquil et al. 2014; Lamine 2011; Van Keulen 1993). In this rationale, "scientists must improve their understanding of the farmer and his practice and vice versa" (McCown 2002). When managing "commons" or shared resources through spatial crop allotment or ecological infrastructure, e.g., corridors, collaboration is needed among farmers and resource-management institutions (Giller et al. 2009; Leeuwis 2004). In such innovation processes, one main role of researchers is to structure and steer the design process (Martin 2015).

Identifying agroecological practices best suited to farmers' production situations and step of the transition requires implementing "adaptive management" processes by trial and error. Adaptive management is a scientific approach particularly adapted to situations with high uncertainty and multiple possible controls via management options (Allen et al. 2011). Developed in the late 1970s in ecology for the management of complex adaptive systems, adaptive management is based on incremental, experiential learning, and decision making, supported by active monitoring of, and feedback from, the effects and outcomes of decisions. Through adaptive management, lessons are learned that consequential actions are always and necessarily specific and embedded in the historical causalities of particular production situations (Jiggins and Röling 2000). A key aspect of adaptive management is the acknowledgement of uncertainty. It is thus built on devising experiments to reduce that uncertainty and collect information about the system. Stakeholders then learn from the outcomes of their experiments and redesign their management practices based on the knowledge gained. In this way, stakeholders continuously reconsider the effectiveness of the management practices implemented, the accuracy of predicted consequences of actions, the relation between actions and indicators, and learn about trade-offs. Through adaptive management, stakeholders gradually and implicitly acquire a wide range of perceptual and cognitive skills.

Adaptive management generally relies on two cyclical and iterative steps:

(i) Step 1 aims to define a set of actions, i.e., designing and a monitoring plan based on farmers' objectives. When implementing biodiversity-based agriculture for farming 
systems, objectives are to design a spatiotemporal distribution of planned biodiversity (e.g., through implementation of crop rotations, crop patterns, crop-livestock interactions, cover crops during fallow periods, and landscape elements) and associated biodiversity that is practice dependent (e.g., sowing timing and sequences, date and method of cover-crop destruction, fertilization, and plant protection). For this task, there is great need for designing and developing tools that can stimulate knowledge exchanges. User-friendliness is also an important key point, as is the accuracy of predicted effects of management practices, because the main objective is to design a coherent foundation of the complex agroecosystem to implement and manage.

(ii) Step 2 aims to monitor changes in agroecosystem structure and ecosystem service levels during the transition. The monitoring lasts a few months for annual crops up to several years for setting up no-tillage cropping systems or for "managing" a landscape. Field indicators usable by farmers are essential for monitoring. Feedback can be used to plan management in subsequent years in the same situation or for other farmers in similar contexts.

Studies about adaptive management in IPM (Shea et al. 2002), conservation agriculture (Moore 2011), and organic farming (Kirschenmann 2009) provide deeper analyses of how this type of adaptive learning and management processes can be implemented.

In summary, we highlight two main difficulties in implementing biodiversity-based agriculture from current knowledge in ecology and agronomy. The first challenge is that strong uncertainties exist about relations between agricultural practices, ecological processes, and ecosystem services. The second challenge is that agroecological practices required to deliver ecosystem services are site specific. The review shows that an adaptive management approach, focusing on planning and monitoring, can serve as a framework for developing and implementing learning tools tailored for biodiversity-based agriculture and for overcoming the above-mentioned difficulties.

\section{Building learning support tools to link principles and actions}

\subsection{Necessary tool features for implementation of biodiversity-based agriculture}

One great challenge for researchers seeking to provide useful knowledge to farmers implementing biodiversity-based agriculture is to develop learning tools that ease understanding and transfer of this knowledge. Such learning tools aim to facilitate and stimulate learners' cognitive processing, especially in situations of high uncertainty (Duru and Martin-Clouaire 2011; Martin 2015). They are designed to be used in a farmer-centered participatory setting (Klerkx et al. 2012) that facilitates: (i) elicitation and understanding of traditional and experiential knowledge about local ecosystems (Malézieux 2011), (ii) assessment of risks associated with new practices (Le Gall et al. 2011), (iii) integration of scientific and local knowledge (Martin 2015), and (iv) the learning process through knowledge sharing, interaction and adaptive-management processes. Most importantly, only farmers are able to detail the situations of action/ management in which they find themselves (Duru 2013).

Developing learning tools to support biodiversity-based agriculture is a particular challenge since: (i) variability and ambiguity in the results of an experiment increase the risk of erroneous learning, in which the learner draws incorrect conclusions, while stochasticity in results can also forestall investigation, when an unlucky first experience discourages further experimentation; (ii) delays between actions and effects due to slow ecological processes can complicate implementation; and (iii) it is difficult to accumulate and organize information produced by experimental and monitoring activities that can be stimulated by learning tools

Three main features of learning tools are required to insure their effectiveness in supporting participatory learning and change in practices: saliency, legitimacy, and credibility (Cash et al. 2003). In the case of biodiversity-based agriculture, we identify key criteria that these tools should satisfy to have these features.

For saliency, which is the relevance to the intended users, tools classically must purposely consider characteristics of the context in which users manage and act (Bergen 2001). They must provide farmers with information allowing them to put knowledge into practice. When built for designing management practices, the scale at which the tools are to be applied should be clearly defined (Martin 2015). Therefore, the resolution of the system under consideration should be carefully chosen in terms of space (plot, set of plots), time (day, week, growing season, interlactation period), and functional entities (biotic and abiotic components), considering, in particular, stakeholders' definition of the problem situation (Pahl-Wostl and Hare 2004). In addition, the tools must incorporate uncertainty due to relations between management, biodiversity and ecosystem services, in addition to the uncertainty caused by contextual factors such as climatic conditions. Tools need to be user-friendly and easily implementable because agricultural stakeholders' time is limited (Dionnet et al. 2013). Finally, learning tools must be flexible and robust, i.e., adaptable and adapted to a wide range of biophysical and farming contexts (see Section 2.2.2; Giller et al. 2009; Martin 2015).

For legitimacy, which we define as "respecting stakeholders' values and their management principles," two criteria are pertinent: (i) the transparency of the design tools and (ii) 
the ability of participants to include their own experiential knowledge when scientific knowledge is lacking or considered to be less suited (Bammer 2005; Martin 2015). It implies building and using relatively simple tools, flexible enough to allow interactive integration of new information and immediately see the results (Eikelboom and Janssen 2013). It also implies that the support tool can represent the system and its environment with the type of information usually used by farmers to make management decisions, e.g., temperature, rainfall, available soil water, and amount of input.

Credibility concerns the scientific trustworthiness of the technical evidence and scientific documentation. This feature is provided by the use of up-to-date scientific knowledge and by well-founded design and evaluation methods (Giller et al. 2009). Scientific knowledge is particularly needed to represent relations between management practices, biodiversity, and ecosystem services, and develop methods to assess model uncertainties.

\subsection{Analysis of weaknesses of some learning support tools and promises for defining research avenues}

Considering the biodiversity-based agriculture management issues and expected features of learning tools, we identify in this section the main limits of existing tools based on scientific knowledge and examples of promising ones. To present promising ones, we distinguish tools targeted at assisting farming system and landscape design from those targeted at monitoring ecosystem-service change in these systems, the two key steps of adaptive management (Section 3.2).

\subsubsection{Limits of existing tools for supporting biodiversity-based agriculture}

Researchers, farmers, and agricultural advisors are not wellequipped to deal with complex adaptive system dynamics. Few mechanistic models dealing with agroecosystems address relations among management, biodiversities, and input and agricultural services. Most existing models focus on representations of the plant-soil-atmosphere system with mechanistic modeling of abiotic resources flows (water, $\mathrm{N}, \mathrm{C}$, and energy). Recently, some modeling approaches have been developed to represent the impact of cropping practices and agricultural mosaics at the landscape level on pest dynamics (e.g., LôPelzer et al. 2010 for phoma stem canker on oilseed rape; Vinatier et al. 2011 for Cosmopolites sordidus on banana). However, these approaches usually require input variables that are difficult to estimate at the landscape level and address only a small part of the biological community, all of which should be considered for biodiversity-based agriculture. Furthermore, these spatially explicit models usually require intensive calculations, which can prevent the use of optimization techniques for the design of innovative agroecological strategies that enhance the pest regulation service. Mathematical networks are promising methods to address management of food webs or the collective management of slightly endocyclic pests (Tixier et al. 2013a, b). Mathematical complexity and inflexibility (Jones et al. 1997) and high uncertainty of the embedded knowledge and parameters of these modeling approaches often decreases their reliability and prevents their use for a given production situation or management objective (Rosenzweig et al. 2012; Tixier et al. 2013a, b). Furthermore, this kind of hard approach is criticized for relying on "black box" models that lack transparency (Leeuwis 2004; McCown et al. 2009).

Unlike mechanistic models, statistical models based on ecological groups have been applied in several fields of ecology. However, they have two limitations: results (i) usually cannot be transferred to sites other than those used to develop the model (i.e. lack generality) and (ii) are usually not useful for developing or managing diversified agroecosystems. For example, knowledge about grassland ecosystem services has greatly increased through the use of the "trait" approach (e.g., Gardarin et al. 2014); however, stakeholders cannot use it for their own situations because it is too time consuming and requires specific skills. New research projects have been launched to bridge this gap through a simplified plant functional-group method (Duru et al. 2013). For other, more complex ecological groups (soil biota and viruses), research results have at least allowed construction of conceptual models of agroecosystems or definition of proxies of traits (Barrios 2007; Cortois and Deyn 2012; Friesen 2010) that are essential for learning about the groups, but not sufficiently adapted to put knowledge into practice. For cropping systems based on a variety of mixtures, intercrops, cover crops, and complex rotations, we lack simple operational models and, to our knowledge, the ecological-group approach has not yet produced the successful results it promised. Accordingly, farmers and their advisors lack tools to put biodiversitybased practices into action while coping with uncertainties.

\subsubsection{Promising tools for designing diversified farming systems and landscapes}

Given the features of learning tools (Section 4.1) and the above-mentioned weaknesses of the main existing tools, we identify two main types of emergent support tools likely to support biodiversity-based agriculture. They are (i) knowledge bases that contain structured scientific facts and empirical information compiled from cumulative experiences and demonstrated skills and that enable biodiversity management to be inferred in specific situations and (ii) model-based games to stimulate knowledge exchange and learning about the effects of planned and associated biodiversity on ecosystem services. We illustrate each with examples of promising tools, 
and we examine the extent to which the three necessary criteria (saliency, legitimacy, and credibility) are fulfilled.

Knowledge bases have been developed recently to help choose cover-crop species by providing information about suitable production situations (main cropping system, climate, and soil) and expected ecosystem services. Some are built from plant-trait-based functional profiles (Damour et al. 2014; Ozier-Lafontaine et al. 2011), while others rely on expert knowledge about plant features (e.g., Naudin et al., unpublished paper). These kinds of supports are considered salient and legitimate by farmers involved in a biodiversitybased agriculture process since they provide key information about potential planned biodiversity that they can implement. However, we think that this information can be reinforced with deeply rooted knowledge from ecological science about interactions between biotic and abiotic factors and between organisms (e.g., nature of competitive and facilitative interactions). This may allow plant sequences and species mixtures to be designed, as well as enlarge the scope towards more numerous trophic levels to account for the soil food web. This direction may also be chosen for "push-pull" technology, a strategy for controlling pests using repellent "push" plants and trap "pull" plants (Khan et al. 2011) to generalize it to a greater number of organisms or production situations. Most of all, to ensure legitimacy, we think it necessary to develop "interactive" knowledge databases that can incorporate farmerexperience feedback in a wide range of farming conditions. Such interactive approaches are already used for agrobiodiversity conservation via seed exchanges among farmers (Pautasso et al. 2013).

A second type of knowledge-based approach for dealing with complexity consists of using an inferential method for qualitative hierarchical multiattribute decision modeling, to cope with complexity while searching for operational outputs. Based on a two-level categorization of the degree of endocyclism of harmful organisms, Aubertot and Robin (2013) built an innovative modeling framework (IPSIM, Injury Profile SIMulator) that combines vertical (control methods) and horizontal (different pests: weeds, plant pathogens, and animal pests) dimensions of IPM. The qualitative hierarchical approach allows representation of effects of three main drivers of crop-injury profiles: (i) soil and climate, (ii) cropping practices, and (iii) landscape structure. Model users can use it $e x$ ante to design IPM strategies suited for their production situations. Due to the lack of data on composite harmful biodiversity (i.e., multiple pests and beneficial organisms), IPSIM models are developed by integrating knowledge from a thorough analysis of scientific and technical literature and consultation with expert panels (Robin et al. 2013). This innovative approach, combining databases and qualitative modeling helps to bridge the gap between scientific knowledge and implementation of biodiversity-based agriculture. It is already used for teaching in French agricultural engineering schools and international training sessions on modeling for sustainable management of crop health. We think that other ecological features and interaction data with abiotic factors for organisms, provided respectively by researchers and users, could be used in such a method.

Model-based games involving scientists, farmers, and other stakeholders combined with biophysical simulation models can be used to perform iterative design and assessment of spatiotemporal distributions of crops, livestock, and seminatural habitats potentially promoting input services. These participatory-design approaches require manipulating "boundary objects" (Jakku and Thorburn 2010; Martin 2015) such as board games, cards, geographic or cognitive maps, and computer models to create a shared language among the actors involved, e.g., farmers, advisors, and students. Material and computer items are used either simultaneously or successively to collectively design and assess alternative farming systems or landscapes. In such approaches, boundary objects and especially computer models are gaining increasing importance as learning and negotiation-support tools (Barreteau et al. 2010; Speelman et al. 2014). Applications of such game-based approaches are now well developed, for example, for crop and grassland allocation to reduce erosion at the landscape level (Souchère et al. 2010), or to design and assess alternative land use and livestock management in livestock systems given farmers' objectives, e.g., transition to organic farming (Martin et al. 2011; Farrié et al. 2015), or to study ecological interactions (facilitation and competition) in a multispecies system to learn how it can be self-organized (Speelman and García-Barrios 2010). In the last example, users are challenged to explore ecological variables and processes to manage a virtual diversified agroecosystem. The principle of the game easily engages players, who can choose how they wish to meet their objectives. However, being based on population-dynamics models, the model is composed of only four organisms, limiting its saliency and future operationality. These model-based game approaches often promote credibility and legitimacy by integrating multiple perspectives through both multidisciplinary scientific knowledge and empirical knowledge. It aims to develop farmers' adaptive capacity by stimulating their reflections and discussions. Ex ante assessment of the systems designed is based on the use of computer models or in combination with multicriteria assessment methods, e.g., MASC approach (Craheix et al. 2012). The latter allow trade-offs between ecosystem services to be identified and subsequently the more satisfying management options to be chosen (Koschke et al. 2013).

Extension of model-based game approaches to more complex processes, such as bio-regulation, needs to be envisioned. For example, the interpretation/description methods (grammar) of Larcher and Baudry (2012) and Sarthou et al. (2014) help determine how structural and functional aspects of 
hedgerows and seminatural habitats can be used to build boundary objects and simplified models that players can use respectively to design alternatives of spatial allocation of these habitats and assess their effects on biological regulations. Gradual integration of scientific and empirical knowledge about interactions between biodiversity and ecosystem services in combined game and model-based approaches seems a promising way to support stakeholders involved in a biodiversity-based agriculture process. Farmers can be involved not only to learn about agroecosystem functioning but also to develop agreements or coordinate their modifications of land use or landscape infrastructure (Tittonell 2014). More broadly, information and communication technology tools other than those presented in this paper may play a decisive role in supporting and shaping relational practices that link social involvement and content management.

\subsubsection{Promising tools for monitoring dynamics of diversified farming systems and landscapes}

A tight in situ assessment of effects of agroecological practices requires well-adapted monitoring methods and management indicators able to reveal aspects of agroecosystems that allow effective or potential levels of corresponding ecosystem services to be estimated. At the crop field or pasture level, such aspects first include the soil state, for which several indicators already exist and are used. However, soil has for too long been considered simply a physicochemical support for plants (most soil indicators used in conventional agriculture are related to its abiotic dimensions), and the consideration that it can also be a habitat for a diverse set of living organisms is a new agricultural issue and a key one in the biodiversity-based agriculture process. Indicators of the balance among noxious, beneficial, and neutral organisms, hence of the real or potential natural pest control of soil, thus have to be made available to farmers, in a simplified form if possible. Above the soil, indicators for planned biodiversity (plants and animals) are also needed. Obviously, many focused on growth dynamics are already available, but new ones are undoubtedly needed for monitoring its effective health and potential health, e.g., at the entire farm level, by estimating the quality of seminatural habitats for sheltering beneficial mobile arthropods that deliver services of pollination and natural pest control. Hence, simple and easy-toimplement indicators about these mobile-agent-based ecosystem services must also be made available to farmers (Kremen et al. 2007). Below, we give three examples to illustrate what this type of ecosystem-service indicator could be.

The visual soil assessment method (Shepherd et al. 2008) was developed to assess components of the soil involved in its fertility, e.g., soil structure, soil porosity, and presence/absence of hardpan. Except for soil texture, the indicators used are sensitive to management regimes and land-use pressure, providing information about dynamics of soil condition. It was developed in collaborative work among scientists, technical officers, and advisors, which increases its legitimacy. It is based on visual assessment of key soil properties listed on a scorecard. This method has high saliency for soil and land managers, who need tools that are reliable, quick, and easyto-use to regularly assess the condition of their soils, their suitability for the crops planned or the best management practices to improve them. It is now widely and regularly used throughout the world and has been endorsed by the Food and Agriculture Organization (FAO), which provides real credibility. However, local interpretation of the results is needed to take local characteristics and key practice $\times$ soil/climate interactions into account.

Despite the close relation between agriculture and biodiversity, surprisingly, little is known about the status of farmland biodiversity and how it changes under different farming practices. A new toolbox, called the "BioBio indicator set," has recently been developed for a variety of farm types and scales in Europe. It is the fruit of a close collaboration among scientists, environmentalists, and farmers, which imparts a good saliency. It measures 23 indicators on farms, addressing all components of farmland biodiversity and management practices. Although this indicator set has recently been developed, its frequent use in international publications for scientists (e.g., Schneider et al. 2014), stakeholders (e.g., Sarthou et al. 2013), and policy makers (e.g., Herzog et al. 2013) will make it better known and probably widely adopted. This may give it high credibility.

For pollination, the FAO developed a standardized method developed by scientists to assess pollination intensity and detect possible pollination deficits in crops (Vaissière et al. 2011). However, this method is limited because it can be used only for homogeneous crops (Vaissière, personal communnication) and is neither widely nor routinely used in the field. Thus, it has good legitimacy but only moderate saliency and credibility, which still need to be assessed. For biological control, such simple, legitimate, and salient indicators still have to be developed, with the hope that they become credible one day. However, results of many studies on relations between landscape heterogeneity (composition and configuration), management practices, and biological control levels (e.g., Rusch et al. 2011; Thies et al. 2011), and several reviews and meta-analyses (e.g., Bianchi et al. 2006; Veres et al. 2013) or models (e.g., Rusch et al. 2012; Vinatier et al. 2009) could be used to develop operational field indicators. Their legitimacy would be high, but their saliency and credibility would still have to be verified. With this objective, several French and international research programs currently underway aim to develop such simple and legitimate indicators. Their saliency should be ensured through the collaboration of field experts and agricultural advisors.

Some well-known and long-established indicators are available to assess agronomic services from biological 
diversity, such as yield and provisioning services in mixed cropping systems evaluated with the land equivalent ratio (Mead and Willey 1980). Besides quantitative agricultural services, qualitative ones can be also expected from enhanced biodiversity in agricultural systems. To this end, classic indicators again are available to assess the gain or loss of quality, such as the level of mycotoxins in mixed or homogeneous crop systems, or the percentage of polyunsaturated fatty acids in milk from cows fed with either a grassland-based or maizesilage-based diet. Similarly, several classic tools already exist to measure (partly) biodiversity-dependent input services, such as soil water and nutrient availability, based on plant and soil physicochemical measurements or observations. Hence, these tools can be used to deliver indicators whose legitimacy, saliency, and credibility are already ensured.

In summary, we identified two main types of emergent support tools likely to contribute to the design and the implementation of biodiversity-based farming systems and landscapes: (i) knowledge bases containing scientific supports and experiential knowledge and (ii) model-based games. Coupled with well-tailored field or management indicators, they allow effects of agroecological practices on biodiversity and ecosystem services to be monitored.

\section{Conclusion and research agenda}

Biodiversity-based agriculture allows several agricultural aspects of the current multidomain crisis to be addressed. It provides a range of ecosystem services allowing chemical input use to be reduced. Compared to the efficiency/ substitution paradigm, biodiversity-based agriculture is more knowledge intensive and requires implementing a more systemic and holistic view of agricultural systems. Currently, biodiversity-based agriculture is marginal, given the current high degree of specialization of farms and regions in productivist rural zones. Some of the principles of biodiversity-based agriculture are partially followed in organic agriculture, conservation agriculture, and IPM, likely due to a partial view of the global challenge that now confronts agriculture. Yet, we have a limited knowledge and understanding of the inherent complexities of biodiversity-based agriculture, leading to few references and little knowledge to use as indicators to support its management.

Our review provides guidelines for overcoming the gap between general scientific knowledge and the site-specific knowledge necessary to promote ecosystem services in a wide range of ecological contexts. It yields a doubly challenging research agenda for the development of (i) knowledge about relations among practices, biodiversity, and associated ecosystem services and (ii) learning-support tools used in an adaptive management perspective. This latter key point will demand a paradigm shift for agricultural science. Researchers have to move from constructing decision-support systems applicable only to simple and controlled situations to learning-support tools that represent the complexity of biodiversity-based agriculture and intended to equip stakeholders involved in the transition towards this form of agriculture. It requires combining research in agricultural science with scientifically based research in ecological, management, and knowledgemanagement sciences:

- Advances in agricultural science include improving links among knowledge-production methods to build learningsupport tools; analytical and modeling methods that are decontextualized (e.g., experimentation, on-farm observations) need to better fit holistic and contextualized methods based on stakeholder participation. This raises questions about the appropriate level of detail that analytical and modeling methods need to have to represent the key biophysical interactions within farming systems and landscapes. Another challenge concerns the "scaling-out" of research methods and findings, i.e., their extrapolation outside the case studies with which they were developed, calibrated, and evaluated. Other questions relate to tool specifications and how to build generic learning tools suitable for a wide diversity of agricultural contexts.

- Advances in ecological science are necessary to characterize planned and associated biodiversity responses to locally controllable drivers, such as agroecological practices at field, farm, and landscape levels, and noncontrollable or exogenous drivers, such as climate change, and effects of biodiversity on ecosystem services. Questions concern the development of indicators to characterize ecosystem services either directly, or indirectly, from related on-farm and landscape biodiversities. Indicators need to be relatively simple but also relevant and userfriendly to be easily applicable to farms and landscapes.

- Advances in management science, especially in participatory science (Warner 2008), are needed to develop methods structured more specifically for collaboration with stakeholders involved in biodiversity-based agriculture and for evaluation of such collaborations. Main scientific questions concern methods to incorporate stakeholder knowledge and feedback into learning supports such as knowledge bases, and the assessment of stakeholders' learning when using learning-support tools.

- Advances in knowledge-management science are expected to help to capture, develop, share, and effectively use decision-making knowledge. Here, knowledgemanagement efforts should focus on integrating and propagating knowledge learned from experiential evidence as well as scientific progress. Questions concern data-reduction and knowledge-representation forms that can enable self-organization of knowledge development and acquisition by a variety of actors. Information and 
communication technology can play a critical role in facilitating rapid, effective, and cost-effective capitalization and management of knowledge, and computer sciences will undoubtedly play a major role in this objective.

Finally, in more general terms, development of scientific knowledge useful for stakeholders involved in the transition towards biodiversity-based agriculture will require taking the position of "integration and implementation sciences", which (i) attempt to provide sound theoretical and methodological foundations to address societal issues characterized by complexity, uncertainty, change, and imperfection; (ii) are based on systems and complex thinking, participatory methods, and knowledge management and exchange; and (iii) are grounded in practical application and involve a large stakeholder panel.

Acknowledgments This paper emerged from work and discussions in four key projects: Locally Adapted Organisms and Organizations (O2LA) funded by the French Agency for Research (ANR-09-STRA08), Modeling for Integrated Crop Management, Assessment and Cropping system design (MICMAC design) funded by the French Agency for Research (ANR-09-STRA-06), Crops and ANimals TOGETHER (CANTOGETHER) funded by the Seventh Framework European Programme (Food, Agriculture and Fisheries, Biotechnology), (FP7, Grant agreement no.: 289328), and Tata-Box (Territorial Agroecological Transition in Action: a tool-box for designing and implementing a transition to a territorial agroecological system in agriculture) funded by the French Agency for Research (ANR-13-AGRO-0006).

Open Access This article is distributed under the terms of the Creative Commons Attribution 4.0 International License (http:// creativecommons.org/licenses/by/4.0/), which permits unrestricted use, distribution, and reproduction in any medium, provided you give appropriate credit to the original author(s) and the source, provide a link to the Creative Commons license, and indicate if changes were made.

\section{References}

Allen CR, Fontaine JJ, Pope KL, Garmestani AS (2011) Adaptive management for a turbulent future. J Environ Manag 92:1339-1345. doi: 10.1016/j.jenvman.2010.11.019

Altieri M (1999) The ecological role of biodiversity in agroecosystems. Agr Ecosyst Environ 74:19-31. doi:10.1016/S0167-8809(99) 00028-6

Amossé C, Jeuffroy M-H, David C (2013) Relay intercropping of legume cover crops in organic winter wheat: effects on performance and resource availability. Field Crop Res 145:78-87. doi:10.1016/j.fcr. 2013.02.010

Anand M, Gonzalez A, Guichard F, Kolasa J, Parrott L (2010) Ecological systems as complex systems: challenges for an emerging science. Divers 2:395-410. doi:10.3390/d2030395

Argyris C, Schön D (1992) Organizational learning: a theory of action perspective. Addison Wesley, Reading, MA

Aubertot J-N, Robin M-H (2013) Injury Profile SIMulator, a qualitative aggregative modelling framework to predict crop injury profile as a function of cropping practices, and the abiotic and biotic environment. I. Conceptual bases. PLoS One 8:e73202. doi:10.1371/ journal.pone.0073202
Bammer G (2005) Integration and implementation sciences : building a new specialization. Ecol Soc 18(2):21

Barnaud C, Antona M, Marzin J (2012) Vers une mise en débat des incertitudes associées à la notion de service écosystémique. VertigO-la revue électronique en sciences de l'environnement 11(1)

Barreteau O, Bots PWG, Daniell KA (2010) A framework for clarifying “ participation " in participatory research to prevent its rejection for the wrong reasons. Ecol Soc 15(2): 1

Barrios E (2007) Soil biota, ecosystem services and land productivity. Ecol Econ 4:269-285. doi:10.1016/j.ecolecon.2007.03.004

Bedoussac L, Justes E (2010) The efficiency of a durum wheat-winter pea intercrop to improve yield and wheat grain protein concentration depends on N availability during early growth. Plant Soil 330(1):19 35. doi:10.1007/s11104-009-0082-2

Bellon S, Hemptinne J-L (2012) Reshaping boundaries between farming systems and the environment. In: Darnhofer I, Gibbon D, Dedieu B (eds.) Farming systems research into the 21st century: the new dynamic. Springer, Dordrecht, pp 307-333

Bennett EM, Peterson GD, Gordon LJ (2009) Understanding relationships among multiple ecosystem services. Ecol Lett 12:1394 13404. doi:10.1111/j.1461-0248.2009.01387.x

Bergen S (2001) Design principles for ecological engineering. Ecol Eng 18:201-210. doi:10.1016/S0925-8574(01)00078-7

Bianchi FJJA, Booij CJH, Tscharntke T (2006) Sustainable pest regulation in agricultural landscapes: a review on landscape composition, biodiversity and natural pest control. Proc R Soc B 273:1715-1727

Biggs R, Schlüter M, Biggs D, Bohensky EL, BurnSilver S, Cundill G, Dakos V, Daw TM, Evans LS, Kotschy K, Leitch AM, Meek C, Quinlan A, Raudsepp-Hearne A, Robards MD, Schoon ML, Schultz L, West PC (2012) Toward principles for enhancing the resilience of ecosystem services. Annu Rev Environ Resour 37:421-448

Bingham IJ, Walters DR, Foulkes MJ, Paveley ND (2009) Crop traits and the tolerance of wheat and barley to foliar disease. Ann Appl Biol 154:159-173. doi:10.1111/j.1744-7348.2008.00291.x

Bommarco R, Kleijn D, Potts SG (2013) Ecological intensification: harnessing ecosystem services for food security. Trends Ecol Evol 28:230-238. doi: 10.1016/j.tree.2012.10.012

Brewer MJ, Goodell PB (2012) Approaches and incentives to implement integrated pest management that addresses regional and environmental issues. Annu Rev Entomol 57:41-59. doi: 10.1146/ annurev-ento-120709-144748

Brouder SM, Gomez-Macpherson H (2014) The impact of conservation agriculture on smallholder agricultural yields: a scoping review of the evidence. Agr Ecosyst Environ 187:11-32. doi:10.1016/j.agee. 2013.08.010

Brussaard L, Caron P, Campbell B et al (2010) Reconciling biodiversity conservation and food security: scientific challenges for a new agriculture. Curr Opin Environ Sustain 2:34-42. doi:10.1016/j.cosust. 2010.03.007

Buman T (2013) Opportunity now: integrate conservation with precision agriculture. J Soil Water Conserv 68:96A-98A

Caporali F (2011) Biodiversity, biofuels, agroforestry and conservation agriculture. Agric. doi:10.1007/978-90-481-9513-8

Cardinale BJ, Duffy JE, Gonzalez A et al (2012) Biodiversity loss and its impact on humanity. Nature 486:59-67. doi:10.1038/nature11148

Cash DW, Clark W, Alcock F, Dickson NM, Eckley N, Guston DH, Mitchell RB (2003) Knowledge systems for sustainable development. PNAS 100:8086-8091

Coquil X, Béguin P, Dedieu B (2014) Transition to self-sufficient mixed crop-dairy farming systems. Renew Agr Food Syst 29:195-205. doi:10.1017/S1742170513000458

Cortois R, Deyn GB (2012) The curse of the black box. Plant Soil 350: 27-33. doi:10.1007/s11104-011-0963

Costanza R, D'arge R, De Groot R, Farber S, Grasso M, Hannon B, Limburg K, Naeem S, O'neill RV, Paruelo J, Raskin RG, Sutton P, 
Van Den Belt M (1997) The value of the world's ecosystem services and natural capital. Nature 387:253-260

Craheix D, Angevin F, Bergez J-E, Bockstaller C, Colomb B, Guichard L, Reau R, Doré T (2012) MASC 2.0, un outil d'évaluation multicritère pour estimer la contribution des systèmes de culture au développement durable. Innov Agron 20:35-48 (in French)

Damour G, Dorel M, Quoc HT, Meynard C, Risède JM (2014) A traitbased characterization of cover plants to assess their potential to provide a set of ecological services in banana cropping systems. Eur J Agron 52:218-228. doi:10.1016/j.eja.2013.09.004

De Groot RS, Alkemade R, Braat L et al (2010) Challenges in integrating the concept of ecosystem services and values in landscape planning, management and decision making. Ecol Complex 7:260-272. doi: 10.1016/j.ecocom.2009.10.006

Dionnet M, Daniell KA, Imache A, von Korff Y, Bouarfa S, Garin P, Jamin J-Y, Rollin D, Rougier J-E (2013) Improving participatory processes through collective simulation: use of a community of practice. Ecol Soc 18(1):36. doi:10.5751/ES-05244-180136

Doltra J, Olesen JE (2013) The role of catch crops in the ecological intensification of spring cereals in organic farming under Nordic climate. Eur J Agron 44:98-108. doi:10.1016/j.eja.2012.03.006

Dordas CA, Lithourgidis AS (2011) Growth, yield and nitrogen performance of faba bean intercrops with oat and triticale at varying seeding ratios. Grass Forage Sci 66:569-577. doi:10.1111/j.1365

Drinkwater LE (2009) Ecological Knowledge: foundation for sustainable organic agriculture in organic farming: the ecological system. Cornell University, Ithaca, Ed Charles Francis, 353 pages

Drinkwater LE, Snapp SS (2007) Nutrients in agroecosystems: rethink the management paradigm. Adv Agron 92:163-186. doi:10.1016/ S0065-2113(04)92003-2

Duru M (2013) Combining agroecology and management science to design field tools under high agrosystem structural or process uncertainty: lessons from two case studies of grassland management. Agr Syst 114:84-94

Duru M, Martin-Clouaire R (2011) Cognitive tools to support learning about farming system management : a case study in grazing systems. Crop Pasture Sci 62:790-802

Duru M, Therond O (2014) Livestock system sustainability and resilience in intensive production zones: which form of ecological modernization? Reg Environ Chang. doi:10.1007/s10113-014-0722-9

Duru M, Jouany C, Le Roux X, Navas ML, Cruz P (2013) From a conceptual framework to an operational approach for managing grassland functional diversity to obtain targeted ecosystem services: case studies from French mountains. Renew Agr Food Syst 29:239 254. doi: $10.1017 / \mathrm{S} 1742170513000306$

EEA (2010) http://www.eea.europa.eu/soer/synthesis/synthesis

Ehrmann J, Ritz K (2014) Plant: soil interactions in temperate multicropping production systems. Plant Soil 376:1-29. doi:10.1007/ s11104-013-1921-8

Eikelboom T, Janssen R (2013) Interactive spatial tools for the design of regional adaptation strategies. J Environ Manage 127 Suppl:S6S14. doi: 10.1016/j.jenvman.2012.09.019

Eisenhauer N, Reich PB, Scheu S (2012) Increasing plant diversity effects on productivity with time due to delayed soil biota effects on plants. Basic Appl Ecol 13:571-578. doi:10.1016/j.baae.2012.09.002

Eviner VT, Hawkes CV (2008) Embracing variability in the application of plant-soil interactions to the restoration of communities and ecosystems. Restor Ecol 16:713-729. doi:10.1111/j.1526-100X.2008. 00482.x

Ewert F, Van Ittersum MK, Heckelei T, Therond O, Bezlepkinae I, Andersen E (2011) Scale changes and model linking methods for integrated assessment of agri-environmental systems. Agr Ecosyst Environ 142:6-17. doi:10.1016/j.agee.2011.05.016

Fahrig L, Baudry J, Brotons L, Burel FG, Crist TO, Fuller RJ, Sirami C, Siriwardena GM, Martin JL (2011) Functional landscape heterogeneity and animal biodiversity in agricultural landscapes. Ecol Lett 14:101-112

Farrié B, Jouven M, Launay F, Moreau J-C, Moulin C-H, Piquet M, Taverne M, Tchakérian E, Thénard V, Martin G (2015) Rangeland Rummy to support adaptive management of rangeland-based livestock systems. J Environ Manag 147:236-245

Fisher B, Turner RK, Morling P (2009) Defining and classifying ecosystem services for decision making. Ecol Econ 68:643-653. doi:10. 1016/j.ecolecon.2008.09.014

Foley JA, Defries R, Asner GP, Barford C, Bonan G, Carpenter SR, Chapin FS, Coe MT, Daily GC, Gibbs HK, Helkowski JH, Holloway T, Howard EA, Kucharik CJ, Monfreda C, Patz JA, Prentice IC, Ramankutty N, Snyder PK (2005) Global consequences of land use. Science NY 309:570-574. doi:10.1126/science. 1111772

Friesen M (2010) Microbially mediated plant functional traits. Annu Rev Ecol Evol S 42:23-46. doi:10.1146/annurev-ecolsys-102710145039

Gaba S, Bretagnolle F, Rigaud T, Philippot L (2014) Managing biotic interactions for ecological intensification of agroecosystems. Front Ecol Evol 2:1-9. doi:10.3389/fevo.2014.00029

Galloway JN, Aber JD, Erisman JW, Seitzinger SP, Howarth RW, Cowling EB, Cosby BJ (2003) The nitrogen cascade. Biosci 53: 331-356

Gardarin A, Garnier E, Carrère P, Cruz P, Andueza D, Bonis A, Colace MP, Dumont B, Duru M, Farruggia A, Gaucherand S, Grigulis K, Kernéïs E, Lavorel S, Louault F, Loucougaray G, Mesléard M, Yaverkovski N, Kazakou H (2014) Plant trait-digestibility relationships across management and climate gradients in permanent grasslands. J Appl Ecol 51:1207-1217

Garnett T, Godfray C (2012) Sustainable intensification in agriculture. Navigating a course through competing food system priorities. Food climate research network and the oxford martin programme on the future of food. University of Oxford, UK

Giampietro M (2002) Complexity and scales: the challenge for integrated assessment. Integr Assoc 3(2-3):247-265

Giller KE, Witter E, Corbeels M, Tittonell P (2009) Field crop res conservation agriculture and smallholder farming in Africa: the heretics' view. Field Crop Res 114:23-34. doi:10.1016/j.fcr.2009.06.017

Godfray HCJ, Beddington JR, Crute IR, Haddad L, Lawrence D, Muir JF, Pretty J, Robinson L, Toulmin (2010) Food security: the challenge of feeding 9 billion people. Science NY 327:812-818. doi:10.1126/ science. 1185383

Greiner R, Patterson L, Miller O (2009) Motivations, risk perceptions and adoption of conservation practices by farmers. Agr Syst 99:86-104. doi:10.1016/j.agsy.2008.10.003

Haddad NM, Brudvig L, Damschen EI, Evans DM, Johnson BL, Levey DJ, Orrock JL, Resasco J, Sullivan LL, Tewksbury JJ, Wagner SA, Weldon AJ (2014) Potential negative ecological effects of corridors. Conserv Biol 28:1178-1187. doi:10.1111/cobi.12323

Herzog F, Balázs K, Dennis P, Friedel J, Geijzendorffer IR, Jeanneret P, Kainz M, Pointereau P (2012) Biodiversity indicators for European farming systems. A guidebook, ART-Schriftenreihe 17. Forschungsanstalt Agroscope Reckenholz-Tänikon ART, Zürich

Herzog F, Jeanneret P, Ammari Y, Angelova S, Arndorfer M, Bailey D, Balázs K, Báldi A, Bogers M, Bunce RGH, Choisis JP, Cuming D, Dennis P, Dyman T, Eiter S, Elek Z, Falusi E, Fjellstad W, Frank T, Friedel JK, Garchi S, Geijzendorffer IR, Gomiero T, Jerkovich G, Jongman RHG, Kainz M, Kakudidi E, Kelemen E, Kölliker R, Kwikiriza N, Kovács-Hostyánszki A, Last L, Lüscher G, Moreno G, Nkwiine C, Opio J, Oschatz ML, Paoletti MG, Penksza K, Pointereau P, Riedel S, Sarthou JP, Schneider MK, Siebrecht N, Sommaggio D, Stoyanova S, Szerencsits E, Szalkovski O, Targetti S, Viaggi D, Wilkes-Allemann J, Wolfrum S, Yashchenko S, Zanetti T (2013) Measuring farmland biodiversity. Solut 4(4):52-58 
Hill SB (1998) Redesigning agroecosystems for environmental sustainability: a deep systems approach. Syst Res 15:391-402

Hill SB, MacRae RJ (1995) Conceptual frameworks for the transition from conventional to sustainable agriculture. J Sustain Agricult $7(1), 81-87$

Horlings LG, Marsden TK (2011) Towards the real green revolution? Exploring the conceptual dimensions of a new ecological modernization of agriculture that could "feed the world". Global Environ Chang 21:441-452. doi:10.1016/j.gloenvcha.2011.01.004

Ingram J (2008) Agronomist-farmer knowledge encounters: an analysis of knowledge exchange in the context of best management practices in England. Agric Hum Values 25:405-418. doi:10.1007/s10460008-9134-0

Ingram J (2010) Technical and social dimensions of farmer learning: an analysis of the emergence of reduced tillage systems in England. J Sustain Agric 34:183-201

Ittersum M K, Van and Rabbinge R (1997) Concepts in production ecology for analysis and quantification of agricultural input-output combinations. Field Crops Res 52:197-208

Jakku E, Thorburn PJ (2010) A conceptual framework for guiding the participatory development of agricultural decision support systems. Agric Syst 103:675-682. doi:10.1016/j.agsy.2010.08.007

Jiggins J, Roling N (2000) Adaptive management: potential and limitations for ecological governance. Int J Agric Resour Gov Ecol 1:2842

Jones JW, Thornton PK, Hansen JW (1997) Opportunities for systems approaches at the farm scale. In: Teng PS, Kropff MJ, HFMTen B, Dent JB, Lansigan FP, van Laar HH (eds) Applications of systems approaches at the farm and regional levels. Kluwer Academic Publishers, The Netherlands, pp 1-18

Jonsson M, Buckley HL, Case BS, Wratten SD, Hale RJ, Didham RK (2012) Agricultural intensification drives landscape-context effects on host-parasitoid interactions in agroecosystems. J Appl Ecol 49(3):706-714

Justes E, Beaudoin N, Bertuzzi P, Charles R, Constantin J, Dürr C, Hermon C, Joannon A, Le Bas C, Mary B, Mignolet C, Montfort F, Ruiz L, Sarthou J-P, Souchère V, Tournebize J, Savini I, Réchauchère $O$ (2012) The use of cover crops to reduce nitrate leaching. Effect on the water and nitrogen balance and other ecosystem services. The international fertiliser society meeting, Cambridge, UK, 7th December 2012. Proceedings 719. ISBN 978-0-85310-356-1

Kassam A, Friedrich T, Reeves T, Pretty J (2011) Production systems for sustainable intensification. Integrating Productivity with EcosystemServices. Proceedings of the conference "Technologie Assessment - Theorie und Praxis 20". Jg., Heft 2, Juli 2011, 38-45

Khan Z, Midega C, Pittchar J, Pickett J, Bruce T (2011) Push-pull technology: a conservation agriculture approach for integrated management of insect pests, weeds and soil health in Africa. Int J Agric Sustain 9:162-170. doi:10.3763/ijas.2010.0558

Kirschenmann F (2009) Farming in the middle: an ethical imperative. In Francis, C. (ed.) Organic farming: the ecological system. Agron. Monogr. 54:325-342

Klerkx L, van Mierlo B, Leeuwis C (2012) Evolution of systems approaches to agricultural innovation: concepts, analysis and interventions. In: Darnhofer I, Gibbon D, Dedieu B (eds) Farming systems research into the 21 st century: the new dynamic. Springer, Dordrecht, pp 359-385

Koohafkan P, Altieri M, Gimenez EH (2011) Green agriculture: foundations for biodiverse, resilient and productive agricultural systems. Int J Agric Sustain 10:61-75. doi: 10.1080/14735903.2011.610206

Koschke L, Fürst C, Lorenz M, Witt A, Frank S, Makeschin F (2013) The integration of crop rotation and tillage practices in the assessment of ecosystem services provision at the regional scale. Ecol Indic 32: 157-171. doi:10.1016/j.ecolind.2013.03.008
Kremen C, Miles A (2012) Ecosystem services in biologically diversified versus conventional farming systems: benefits , externalities , and trade-offs. Ecological and society 17:40

Kremen C, Iles A, Bacon C (2012) Diversified farmings: an agroecological, systems-based. Ecol Soc 17(4):44

Kremen C, Williams NM, Aizen MA, Gemmill-Herren, LeBuhn G, Minckley R, Packer L, Potts SG, Roulston T, Steffan-Dewenter I, Vázquez DP, Winfree R, Adams L, Crone EE, Greenleaf SS, Keitt TH, Klein AM, Regetz J, Ricketts TH (2007) Pollination and other ecosystem services produced by mobile organisms: a conceptual framework for the effects of land-use change. Ecology letters 10: 299-314. doi:10.1111/j.1461-0248.2007.01018.x

Kruess A, Tscharntke T (2000) Species richness and parasitism in a fragmented landscape: experiments and field studies with insects on vicia sepium. Oecologia 122:129-137

Lamine C (2011) Transition pathways towards a robust ecologization of agriculture and the need for system redesign. Cases from organic farming and IPM. J Rural Stud 27:209-219. doi:10.1016/j.jrurstud. 2011.02.00

Landis DA, Wratten SD, Gurr GM (2000) Habitat management to conserve natural enemies of arthropod pests in agriculture. Annu Rev Entomol 45:175-201

Larcher F, Baudry J (2012) Landscape grammar: a method to analyse and design hedgerows and networks. Agrofor Syst 87:181-192. doi:10. 1007/s10457-012-9534-4

Lassaletta L, Billen G, Grizzetti B, Garnier J, Leach AM, Galloway JM (2014) Food and feed trade as a driver in the global nitrogen cycle: 50-year trends. Biogeochem 118:225-241. doi:10.1007/s10533013-9923-4

Lavorel S, Garnier E (2002) Predicting changes in community composition and ecosystem functioning from plant traits: revisiting the holy grail. Funct Ecol 16:545-556. doi:10.1046/j.1365-2435.2002. 00664.x

Lavorel S, Storkey J, Bardgett RD et al (2013) A novel framework for linking functional diversity of plants with other trophic levels for the quantification of ecosystem services. J Veg Sci 24:942-948. doi:10. 1111/jvs.12083

Le Gal P-Y, Dugué P, Faure G, Novak S (2011) How does research address the design of innovative agricultural production systems at the farm level? A review. Agr Syst 104:714-728. doi:10.1016/j. agsy.2011.07.007

Le Roux R, Barbault J, Baudry J, Burel F, Doussan I, Garnier E, Herzog F, Lavorel S, Lifran R, Roger-Estrade J, Sarthou JP, Trommetter M (éditeurs) (2008): agriculture et biodiversité, valoriser les synergies. Expertise scientifique collective, synthèse du rapport, INRA. Paris, France: 738 pages

Leeuwis C (2004) Communication for rural innovation: rethinking agricultural extension. Blackwell Publishing Ltd, Oxford, UK

Levidow L, Birch K, Papaioannou T (2012) EU agri-innovation policy : two contending visions of the bio-economy. Crit Policy Stud 6:3741

Lin BB, Flynn DFB, Bunker DE, Uriarte M (2011) The effect of agricultural diversity and crop choice on functional capacity change in grassland conversions. Synthesis 48:609-618. doi: 10.1111/j.13652664.2010.01944.x

Lô-Pelzer E, Bousset L, Jeuffroy MH, Salam MU, Pinochet X, Boillot M, Aubertot JN (2010) SIPPOM-WOSR: a simulator for integrated pathogen population management of phoma stem canker on winter oil seed rape. I. Description of the model. Field Crop Res 118:73-81

Lüscher G, Jeanneret P, Schneider K, Turnbull LA, Arndorfer M, Balázs K, Báldi A, Bailey D, Bernhardt KG, Choisis JP, Elek Z, Frank T, Friedel JK, Kainz M, Kovács-Hostyánszki A, Oschatz M, Paoletti MG, Papaja-Hülsbergen S, Sarthou JP, Siebrecht N, Wolfrum S, Herzog F (2014) Responses of plants, earthworms, spiders and bees to geographiclocation, agricultural management and surrounding 
landscape in European arable fields. Agr Ecosyst Environ 186:124 134

Mace GM, Norris K, Fitter AH (2012) Biodiversity and ecosystem services: a multilayered relationship. Trends Ecol Evol 27:19-26. doi: 10.1016/j.tree.2011.08.006

MacLeod A, Wratten SD, Sotherton NW, Thomas MB (2004) Beetle banks' as refuges for beneficial arthropods in farmland: long-term changes in predator communities and habitat. Agric Forest Entomol $6(2): 137-153$

Malézieux E (2011) Designing cropping systems from nature. Agr Sustain Dev. doi:10.1007/s13593-011-0027-z

Marsden T (2012) Towards a real sustainable agri-food security and food policy: beyond the ecological fallacies? Polit Quart 83:139-145. doi:10.1111/j.1467-923X.2012.02242.x

Martin G (2015) A conceptual framework to support adaptation of farming systems - development and application with Forage Rummy. Agr Syst 132:52-61

Martin G, Felten B, Duru M (2011) Forage rummy: a game to support the participatory design of adapted livestock systems. Environ Model Software 26:1442-1453. doi:10.1016/j.envsoft.2011.08.013

McCown R (2002) Changing systems for supporting farmers' decisions: problems, paradigms, and prospects. Agr Syst 74:179-220. doi:10. 1016/S0308-521X(02)00026-4

McCown R, Carberry P, Hochman Z, Dalgliesh N, Foale M (2009) Reinventing model-based decision support with Australian dryland farmers. 1. Changing intervention concepts during 17 years of action research. Crop Pasture Sci 60:1017-1030. doi:10.1071/ CP08455

Mead R, Willey RW (1980) The concept of a land equivalent ratio and advantages in yield from inter-cropping. Exp Agric 16:217-218

Médiène S, Valantin-morison M, Sarthou J, De Tourdonnet S, Gosme M, Bertrand M, Roger-Estrade J, Aubertot JN, Rusch A, Motisi N, Pelosi C, Doré T (2011) Agroecosystem management and biotic interactions : a review. Agr Sustain Dev 31:491-514. doi:10.1007/ s13593-011-0009-1

Millennium ecosystem assessment. Ecosystems and human well-being: biodiversity synthesis. World Resources Institute [online] (2005) www.millenniumassessment.org/en/Synthesis.html

Moonen A, Ba P (2008) Agriculture, ecosystems and environment functional biodiversity: an agroecosystem approach. Methodol 127:721. doi:10.1016/j.agee.2008.02.013

Moore KM (2011) Global networks in local agriculture: a framework for negociation. J Agric Food Inf 12:23-39

Navas M-L (2012) Trait-based approaches to unravelling the assembly of weed communities and their impact on agro-ecosystem functioning. Weed Res 52:479-488. doi:10.1111/j.1365-3180.2012.00941.x

O'Rourk ME, Sappington TW, Fleischer SJ (2010) Managing resistance to bt crops in a genetically variable insect herbivore, ostrinia nubilalis. Ecol Appl 20:1228-1236

Ozier-Lafontaine H, Publicol M, Blazy JM, Melfort C (2011) SIMSERV: Expert system of assistance to the selection of plants of service for various agro-ecological and socio-economic contexts. Licence CeCILL http://toolsforagroecology.antilles.inra.fr/simserv

Pahl-wostl C, Hare M (2004) Processes of social learning in integrated resources management. J Commun Appl Soc Psychol 206:193-206. doi: $10.1002 /$ casp. 774

Pahl-Wostl C, Holtz G, Kastens B, Knieper C (2010) Analyzing complex water governance regimes: the management and transition framework. Environ Sci Policy 13:571-581. doi:10.1016/j.envsci.2010. 08.006

Parrott L (2010) Measuring ecological complexity. Ecol Indic 10(6): 1069-1076. doi:10.1016/j.ecolind.2010.03.014

Parrott L, Latombe G (2012) Agents, individuals, and networks: modeling methods to inform natural resource management in regional landscapes. Ecology and Society 17:32
Pautasso M, Aistara G, Barnaud A et al (2013) Seed exchange networks for agrobiodiversity conservation. A review. Agr Sustain Dev 33: 151-175. doi:10.1007/s13593-012-0089-6

Pelosi G, Goulard M, Balent G (2010) The spatial scale mismatch between ecological processes and agricultural management: do difficulties come from underlying theoretical frameworks? Agric Ecosyst Environ 139:455-462

Pisante M, Stagnari F, Acutis M, Bindi M, Brilli L, di Stefano V, Carrozi R (2015) Conserv Agric Clim Chang 805:579-620

Pittelkow CM, Liang X, Linquist BA, van Groenigen KJ, Lee J, Lundy ME, van Gestel N, Six J, Venterea RT, van Kessel C (2014) Productivity limits and potentials of the principles of conservation agriculture. Nature 517:365-368. doi:10.1038/nature13809

Ponisio LC, Gonigle LKM, Mace KC, Palomino P, de Valpine P, Kremen C (2014) Diversification practices reduce organic to conventional yield gap. Philos Trans Royal Soc B: Biol Sci 282:20141396. doi: 10.1098/rspb.2014.1396

Power AG (2010) Ecosystem services and agriculture: tradeoffs and synergies. Phil. Trans R Soc B 365:2959-2971

Pretty J, Toulmin C, Williams S (2011) Sustainable intensification in African agriculture. Int J Agric Sustain 9(1):5-24

Quijas S, Schmid B, Balvanera P (2010) Plant diversity enhances provision of ecosystem services: a new synthesis. Basic Appl Ecol 11: 582-593. doi:10.1016/j.baae.2010.06.009

Rabbinge R, De Wit CT (1989) Systems, models and simulation. In: Rabbinge R, Ward SA, Van Laar HH (eds) Simulation and systems management in crop protection. Pudoc, Wageningen, pp 3-15

Ratnadass A, Fernandes P, Avelino J, Habib R (2012) Plant species diversity for sustainable management of crop pests and diseases in agroecosystems: a review. Agr Sustain Dev 32:273-303. doi:10. 1007/s13593-011-0022-4

Raunkiær C (1934) The life forms of plants and statistical plant geography. Clarendon Press, Oxford

Robin MH, Colbach N, Lucas P, Montfort F, Cholez C, Debaeke P, Aubertot JN (2013) Injury Profile SIMulator, a qualitative aggregative modelling framework to predict injury profile as a function of cropping practices, and abiotic and biotic environment. II. Proof of concept: design of IPSIM-Wheat-Eyespot. Plos One 8(10):e75829. doi:10.1371/journal.pone.0075829

Röling NG, Wagmakers MAE (eds) (1998) Facilitating sustainable agriculture. Participatory learning and adaptive management in times of environmental uncertainty. Cambridge University Press, Cambridge

Rosenzweig C, Jones JW, Hatfield JL, Ruane AC, Boote KJ, Thorburn P, Antle JM, Nelson GC, Porter C, Janssen J, Asseng S, BassoB, Ewert F, Wallach D, Baigorria GWinter JM (2012) The Agricultural Model Intercomparison and Improvement Project (AgMIP): protocols and pilot studies. Agr Forest Meteorol 170:166-182. doi: 10.1016/ j.agrformet.2012.09.011

Rusch A, Valantin-Morison M, Sarthou JP, Roger-Estrade J (2010) Biological control of insect pests in agroecosystems: effects of crop management, farming systems, and seminatural habitats at the landscape scale: a review. Adv Agron 109:219-259

Rusch A, Valantin-Morison M, Sarthou JP, Roger-Estrade J (2011) Multiscale effects of landscape complexity and crop management on pollen beetle parasitism rate. Land Ecol 26:473-486

Rusch A, Valantin-Morison M, Roger-Estrade J, Sarthou JP (2012) Using landscape indicators to predict high pest infestations and successful natural pest control at the regional scale. Land Urban Plan 105:6273. doi:10.1016/j.landurbplan.2011.11.021

Sarthou JP, Choisis JP, Amossé A, Arndorfer M, Bailey D, Balázs K, Balent G, Deconchat M, Dennis P, Eiter S, Fjellstad W, Friedel JK, Jeanneret P, Jongman RH, Kainz M, Moreno G, Ouin A, Paoletti MG, Pointereau P, Stoyanova S, Viaggi D, Vialatte A, Wolfrum S, Herzog F (2013) Indicateurs de biodiversité dans les exploitations agricoles biologiques et conventionnelles des vallées 
et coteaux de Gascogne, cas d'étude français du projet européen BIOBIO. Innovations Agronomiques 32:333-349

Sarthou JP, Badoz A, Vaissière B, Chevallier A, Rusch A (2014) Local more than landscape parameters structure natural enemy communities during their overwintering in semi-natural habitats. Agr Ecosyst Environ 194:17-28

Scherr SJ, McNeely JA (2008) Biodiversity conservation and agricultural sustainability: towards a new paradigm of "ecoagriculture" landscapes. Philos T R Soc Lond B 363:477-494. doi:10.1098/rstb. 2007.2165

Schneider MK, Lüscher G, Jeanneret P, Arndorfer M, Bailey D, Balács K, Dennis P, Fjellstad W, Friedel JK, Jongman RHG, Kainz M, Moreno G, Paoletti MG, Pointereau P, Sarthou JP, Siebrecht D, Sommaggio J, Wolfrum S, Herzog F (2014) Gains to species diversity in organically farmed fields are not propagated at the farm level. Nature Communications 5:4151

Schutter de O, Vanloqueren G (2011) The new green revolution: how twenty-first-century science can feed the world. Solutions 2:33-44

Sebillotte M (1990) Système de culture, un concept opératoire pour les agronomes. In : L Combe et D Picard coord, Les systèmes de culture Inra, Versailles: 165-196

Serna-Chavez HM, Schulp CJE, Van Bodegom PM, Bouten W, Verburg PH, Davidson MD (2014) A quantitative framework for assessing spatial flows of ecosystem services. Ecol Indic 39:24-33. doi:10. 1016/j.ecolind.2013.11.024

Shea K, Possingham HP, Murdoch WW, Roush R (2002) Active adaptive management in insect pest and weed control: intervention with a plan for learning. Ecol Appl 12:927-936. doi:10.1890/10510761(2002)012[0927:AAMIIP]2.0.CO;2

Shennan C (2008) Biotic interactions, ecological knowledge and agriculture. Philos T R Soc Lond B 363:717-739. doi:10.1098/rstb.2007.2180

Shepherd TG, Stagnari F, Pisante M, Benites J (2008) Visual soil assessment-field guide for annual crops. FAO, Roma, Italy

Singh JS, Pandey VC, Singh DP (2011) Efficient soil microorganisms: a new dimension for sustainable agriculture and environmental development. Agr Ecosyst Environ 140:339-353. doi:10.1016/j.agee. 2011.01.017

Smith RG, Gross KL, Robertson GP (2008) Effects of crop diversity on agroecosystem function: crop yield response. Ecosystems 11:355366. doi:10.1007/s10021-008-9124-5

Souchère V, Millair L, Echeverria J, Bousquet F, Le Page C, Etienne M (2010) Co-constructing with stakeholders a role-playing game to initiate collective management of erosive runoff risks at the watershed scale. Environ Model Software 25:1359-1370. doi:10.1016/j. envsoft.2009.03.002

Speelman EN, García-Barrios LE (2010) Agrodiversity v. 2: an educational simulation tool to address some challenges for sustaining functional agrodiversity in agro-ecosystems. Ecol Model 221:911918. doi:10.1016/j.ecolmodel.2009.12.007

Speelman EN, García-Barrios LE, Groot JCJ, Tittonell P (2014) Gaming for smallholder participation in the design of more sustainable agricultural landscapes. Agr Syst 126:62-75. doi:10.1016/j.agsy.2013. 09.002

Sutherland L-A, Burton RJF, Ingram J, Blackstock K, Slee B, Gotts N (2012) Triggering change: towards a conceptualisation of major change processes in farm decision-making. J Environ Manag 104: 142-151. doi:10.1016/j.jenvman.2012.03.013

Swenson S, Moore KM, Tech V (2009) Developing conservation agriculture production systems : an analysis of local networks. Communication 1-46

Swinton SM, Lupi F, Robertson GP, Hamilton SK (2007) Ecosystem services and agriculture: cultivating agricultural ecosystems for diverse benefits. Ecol Econ 64:245-252

Thies C, Steffan-Dewenter I, Tscharntke T (2003) Effects of landscape context on herbivory and parasitism at different spatial scales. Oikos 101(1):18-25
Thies C, Haenke S, Scherber C, Bengtsson J, Bommarco R, Clement LW, Ceryngier P, Dennis C, Emmerson M, Gagic V, Hawro V, Liira J, Weisser WW, Winqvist C, Tscharntke T (2011) The relationship between agricultural intensification and biological control: experimental tests across Europe. Ecol Appl 21(6):2187-2196

Tilman D, Fargione J, Wolff B, D'Antonio C, Dobson A, Howarth R, Schindler D, Schlesinger WH, Simberloff D, Swackhamer D (2001) Forecasting agriculturally driven global environmental change. Science 292:281-284

Tilman D, Cassman KG, Matson PA, Naylor R, Polasky S (2002) Agricultural sustainability and intensive production practices. Nature 418:671-677

Tittonell P (2014) Ecological intensification of agriculture - sustainable by nature. Curr Opin Environ Sustain 8:53-61. doi:10.1016/j.cosust. 2014.08.006

Tixier P, Lavigne C, Alvarez S, Gauquier A, Blanchard M, Ripoche A, Achard R (2011) Model evaluation of cover crops, application to eleven species for banana cropping systems. Eur J Agron 34:53-61. doi:10.1016/j.eja.2010.10.004

Tixier P, Duyck PF, Côte FX, Caron-Lormier G, Malézieux E (2013a) Food web-based simulation for agroecology. Agr Sustain Dev 33: 663-670

Tixier P, Peyrard N, Aubertot JN, Gaba S, Radoszycki J, Caron-Lormier G, Vinatier F, Mollot G, Sabbadin R (2013b) Chapter 7-Modelling interaction networks for enhanced ecosystem services in agroecosystems. Adv Ecol Res 49:437-480

Tscharntke T, Klein AM, Kruess A, Steffan-Dewenter I, Thies C (2005) Landscape perspectives on agricultural intensification and biodiversity-ecosystem service management. Ecol Lett 8(8):857-874

Tscharntke T, Bommarco R, Clough Y, Crist TO, Kleijn D, Rand TA, Tylianakis JM, Van Nouhuys S, Vidal S (2007) Conservation biological control and enemy diversity on a landscape scale. Biol Control 43(3):294-309

Tscharntke T, Tylianakis JM, Rand TA, Didham RK, Fahrig L, Batary P, Bengtsson J, Clough Y, Crist TO, Dormann CF, Ewers RM, Fründ J, Holt RD, Holzschuh A, Klein AM, Kleijn D, Kremen C, Landis DA, Laurance W, Lindenmayer D, Scherber C, Sodhi N, SteffanDewenter I, Thies C, Van Der Putten WH, Westphal C (2012) Landscape moderation of biodiversity patterns and processes - eight hypotheses. Biol Rev. doi:10.1111/j.1469-185X.2011.00216.x

Tsiafouli MA, Thébault E, Sgardelis SP et al (2015) Intensive agriculture reduces soil biodiversity across Europe. Glob Chang Biol 21:973985. doi:10.1111/gcb.12752

Vaissière BE, Freitas BM, Gemmill-Herren B (2011) Protocol to detect and assess pollination deficits in crops: a handbook for its use. FAO, Roma, Italy

Van Keulen H (1993) Options for agricultural development: a case study for Mali's fifth region. In: Systems approaches for agricultural development. FWT Penning de Vries, PS Teng \& Metselaar, K (Eds) Kluwer Academic Publishers, pp. 355-365

Vanloqueren G, Baret PV (2009) How agricultural research systems shape a technological regime that develops genetic engineering but locks out agroecological innovations. Res Policy 38:971-983. doi: 10.1016/j.respol.2009.02.008

Veres A, Petit S, Conord C, Lavigne C (2013) Does landscape composition affect pest abundance and their control by natural enemies? A review. Agr Ecosyst Environ 166:110-117

Vinatier F, Tixier P, Page CL, Duyck PF, Lescourret F (2009) COSMOS, a spatially explicit model to simulate the epidemiology of cosmopolites sordidus in banana fields. Ecol Model 220(18):2244-2254

Warner KD (2008) Agroecology as participatory science emerging alternatives to technology transfer extension practice introduction: the travail of extension. Science Technology Human Values 33:754-77

Williams BK (2011) Adaptive management of natural resources-framework and issues. J Environ Manag 92:1336-1353 
Willocquet L, Aubertot JN, Lebard S, Robert C, Lannou C, Savary S (2008) Simulating multiple pest damage in varying winter wheat production situations. Field Crop Res 107(1):12-28

Wortman SE, Francis C, Bernards ML, Drijber RA, Lindquist JL (2012) Optimizing cover crop benefits with diverse mixtures and an alternative termination method. Agr J 104:1425-1435. doi:10.2134/ agronj2012.0185
Wu J, David J (2002) A spatially explicit hierarchical approach to modelling complex ecological systems: theory and applications. Ecol Model 153:7-26

Zhang W, Ricketts TH, Kremen C, Carney K, Swinton SM (2007) Ecosystem services and dis-services to agriculture. Ecol Econ 64: $253-260$ 